\title{
Group 4 metallocene complexes with non-bridged and tetramethyldisiloxane-bridged methyl-phenyl-cyclopentadienyl ligands: synthesis, characterization and olefin polymerization studies
}

\author{
Gema Martínez, Pascual Royo *, Marta E.G. Mosquera \\ Departamento de Química Inorgánica. Universidad de Alcalá. Campus Universitario, E-28871 Alcalá de Henares, Spain
}

Received 30 April 2004; accepted 30 June 2004

Available online 3 August 2004

\begin{abstract}
The non-vicinal methyl-phenyl-substituted zirconocene dichlorides meso-and rac- $\left[\mathrm{Zr}\left\{\eta^{5}-\left(1-\mathrm{Ph}-3-\mathrm{Me}-\mathrm{C}_{5} \mathrm{H}_{3}\right)\right\}_{2} \mathrm{Cl}_{2}\right]$ and $\left[\mathrm{Zr}\left(\eta^{5}-\right.\right.$ $\left.\left.\mathrm{C}_{5} \mathrm{H}_{5}\right)\left\{\eta^{5}-\left(1-\mathrm{Ph}-3-\mathrm{Me}-\mathrm{C}_{5} \mathrm{H}_{3}\right)\right\} \mathrm{Cl}_{2}\right]$ have been isolated by transmetallation of the lithium salt $\mathrm{Li}\left(1-\mathrm{Ph}-3-\mathrm{Me}^{-\mathrm{C}_{5}} \mathrm{H}_{3}\right)$ to $\mathrm{ZrCl} 4(\mathrm{THF})_{2}$ and $\left[\mathrm{Zr}\left(\eta^{5}-\mathrm{C}_{5} \mathrm{H}_{5}\right) \mathrm{Cl}_{3} \cdot \mathrm{DME}\right](\mathrm{DME}=$ dimethoxyethane), respectively. Similar transmetallation of the lithium salt $\mathrm{Li} 2[(\mathrm{Me}-\mathrm{Ph}-$ $\left.\left.\mathrm{C}_{5} \mathrm{H}_{2} \mathrm{SiMe}_{2}\right)_{2} \mathrm{O}\right]$ to $\mathrm{MCl}_{4}$ gave the ansa-metallocenes $\left[\mathrm{M}\left\{\eta^{5}-\left(\mathrm{Me}-\mathrm{Ph}-\mathrm{C}_{5} \mathrm{H}_{2} \mathrm{SiMe}_{2}\right)_{2} \mathrm{O}\right\} \mathrm{Cl}_{2}\right](\mathrm{M}=\mathrm{Zr}$, Hf $)$ for which the meso- and rac-diastereomers were separated. The dimethyl and dibenzyl derivatives of these metallocenes were also prepared and the structure of all of these compounds determined by NMR spectroscopy. The molecular structure of rac- $\left[\mathrm{Zr}\left\{\eta^{5}-\left(2-\mathrm{Me}^{-4}-\mathrm{Ph}-\mathrm{C}_{5} \mathrm{H}_{2} \mathrm{Si}-\right.\right.\right.$ $\left.\left.\mathrm{Me}_{2}\right)_{2} \mathrm{O}\right\} \mathrm{Cl}_{2}$ ] was determined by single crystal X-ray diffraction methods. The activity of the dichlorometallocenes/MAO catalysts for ethene and propene polymerization was evaluated.
\end{abstract}

(C) 2004 Elsevier B.V. All rights reserved.

Keywords: Cyclopentadienyl; Zirconium; Hafnium; Disiloxane; ansa-Metallocenes; Olefin-Polymerization

\section{Introduction}

Studies related to olefin polymerization processes [1] have oriented most efforts made to design new types of group 4 metallocene compounds using variously substituted cyclopentadienyl, indenyl and fluorenyl ligands and different bridging systems. Tetramethyldisiloxanebridged ansa-metallocenes are an interesting group of complexes. Some lanthanide and group 4 tetramethyldisiloxane-bridged ansa-metallocenes related to the ferrocenophane derivative reported previously [2] have been isolated. We reported $[3,4]$ the preparation of the group 4 metal complexes $\left[\mathrm{M}\left\{\left(\eta^{5}-\mathrm{C}_{5} \mathrm{H}_{4} \mathrm{SiMe}_{2}\right)_{2} \mathrm{O}\right\} \mathrm{Cl}_{2}\right]$ by hydrolysis of the chlorosilyl derivatives $\left[\mathrm{M}\left(\eta^{5}-\mathrm{C}_{5} \mathrm{H}_{4} \mathrm{Si}\right.\right.$

\footnotetext{
* Corresponding author. Tel.: +34-91-8854765; fax: +34-918854683.

E-mail address: pascual.royo@uah.es (P. Royo).
}

$\left.\mathrm{Me}_{2} \mathrm{Cl}\right)_{2} \mathrm{Cl}_{2}$ ] and similar hydrolytic cleavage of $\mathrm{Si}-$ $\mathrm{NMe}_{2}$ bonds gave the tetramethylcyclopentadienyl titanium derivative [5]. These group 4 metal [6] and similar praseodymium and ytterbium [7] compounds with unsubstituted and $t$-butyl-substituted [6,8] cyclopentadienyl rings were isolated following the method reported for the first titanium derivative [9], by reaction of the metal halides with the sodium or potassium salts of the dicyclopentadienyl ligand. The related bis(indenyl) titanium and zirconium complexes were also reported $[10,11]$ and used as catalyst precursors for ethene and propene polymerization [10]. Related doubly-disiloxane-bridged $[12,13]$ and di- and polynuclear monocyclopentadienyl-type titanium complexes [14] have also been isolated and their catalytic activity for styrene polymerization studied [15]. Except for $\left[\mathrm{Ti}\left\{\left(\eta^{5}-\mathrm{C}_{5} \mathrm{Me}_{4} \mathrm{Si}-\right.\right.\right.$ $\left.\left.\mathrm{Me}_{2}\right)_{2} \mathrm{O}\right\} \mathrm{Cl}_{2}$ ] [5] all of the X-ray molecular structures studied for this type of ansa-metallocene compounds 


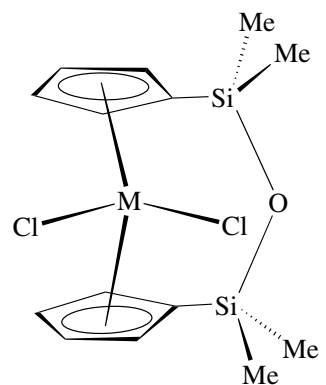

(a)

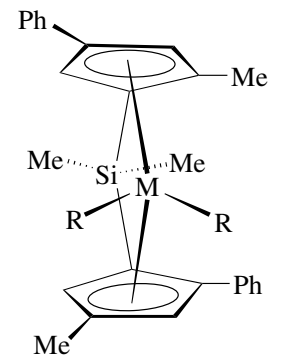

(b)

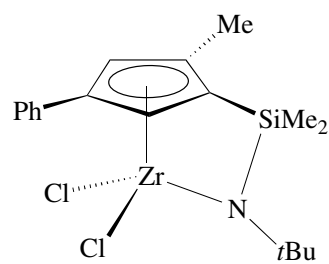

(c)

Scheme 1 .

show the lateral location of the disiloxane bridge with respect to the $\mathrm{MCl}_{2}$ moiety (Scheme 1(a)) with both cyclopentadienyl rings twisted to bring closer two carbon atoms located in $\alpha$ position with respect to the bridge.

Tetramethylethylene- and dimethylsilyl-bridged ansametallocenes with the disubstituted methyl-phenyl-cyclopentadienyl ligand have been reported previously [16] and we have recently prepared [17] one new dimethylsilyl-bridged ansa-zirconocene (Scheme 1(b)) and one Cp-silyl- $\eta^{1}$-amido zirconium complex (Scheme 1(c)) in which the $\mathrm{Me}$ and $\mathrm{Ph}$ groups are always located in 2,4-positions with respect to the bridgehead carbon atom. We were interested in studying the effect of these disubstituted rings on the behaviour of ansa-metallocenes bridged by the tetramethyldisiloxane group compared with the corresponding unbridged metallocenes. In this work we describe the synthesis and structural characterization of $\left[\mathrm{Zr}\left\{\eta^{5}-\left(1-\mathrm{Ph}-3-\mathrm{Me}-\mathrm{C}_{5} \mathrm{H}_{3}\right)\right\}_{2} \mathrm{X}_{2}\right]$ and $\left[\mathrm{Zr}\left(\eta^{5}-\right.\right.$ $\left.\left.\mathrm{C}_{5} \mathrm{H}_{5}\right)\left\{\eta^{5}-\left(1-\mathrm{Ph}-3-\mathrm{Me}-\mathrm{C}_{5} \mathrm{H}_{3}\right)\right\} \mathrm{X}_{2}\right]\left(\mathrm{X}=\mathrm{Cl}, \mathrm{Me}, \mathrm{CH}_{2} \mathrm{Ph}\right)$ zirconocene complexes with non-bridged cylopentadienyl rings and tetramethyldisiloxane-bridged ansa-metallocene derivatives $\left[\mathrm{M}\left\{\eta^{5}-\left(\mathrm{Me}-\mathrm{Ph}-\mathrm{C}_{5} \mathrm{H}_{2} \mathrm{SiMe}_{2}\right)_{2} \mathrm{O}\right\} \mathrm{X}_{2}\right]$ $\left(\mathrm{M}=\mathrm{Zr}\right.$, Hf; $\left.\mathrm{X}=\mathrm{Cl}, \mathrm{Me}, \mathrm{CH}_{2} \mathrm{Ph}\right)$ containing the Me$\mathrm{Ph}$-disubstituted cyclopentadienyl ligand. The catalytic activity of the dichlorozirconocenes combined with MAO for ethene and propene polymerization has been evaluated.

\section{Results and discussion}

\subsection{Dicyclopentadienyl zirconium complexes}

As shown in Scheme 2, reaction of the lithium salt $\mathrm{Li}$ [1-Ph-3-Me- $\left.\mathrm{C}_{5} \mathrm{H}_{3}\right] \mathbf{1}$ [16] with 0.5 equivalents of $\mathrm{ZrCl}_{4}$ in hexane gave the dicyclopentadienyl zirconium complex $\left[\mathrm{Zr}\left\{\eta^{5}-\left(1-\mathrm{Ph}-3-\mathrm{Me}-\mathrm{C}_{5} \mathrm{H}_{3}\right)\right\}_{2} \mathrm{Cl}_{2}\right] \mathbf{2}$ which was isolated as a yellow microcrystalline solid in $74 \%$ yield and characterized by elemental analysis and NMR spectroscopy.

The enantiotopic faces of the disubstituted cyclopentadienyl rings afford a mixture of two diastereomers meso-2 and $r a c-2$ in an almost equimolar ratio (1/0.8). Pure samples of meso-2 and rac-2 could not be isolated by fractional crystallization and they cannot be distinguished by NMR spectroscopy because both show similar patterns of signals in their ${ }^{1} \mathrm{H}$ and ${ }^{13} \mathrm{C}$ spectra. The plane of symmetry of the meso-2 and the $\mathrm{C}_{2}$-axis of the rac-2 isomers make the two cyclopentadienyl rings equivalent exhibiting one singlet for the ring-methyl protons, three multiplets due to the $\mathrm{ABC}$ spin system of the ring protons and the expected three multiplets for two equivalent phenyl rings. Consistently both isomers also show almost identical sets of signals in their ${ }^{13} \mathrm{C}$ NMR spectra (see Section 4). Alkylation of this mixture (meso-2 +rac-2) with 2 equivalents of $\mathrm{LiMe}$ and $\mathrm{MgCl}\left(\mathrm{CH}_{2} \mathrm{Ph}\right)$ gave meso-rac mixtures of the corresponding dimethyl and dibenzyl zirconium complexes $\left[\mathrm{Zr}\left\{\eta^{5}-\left(1-\mathrm{Ph}-3-\mathrm{Me}-\mathrm{C}_{5} \mathrm{H}_{3}\right)\right\}_{2} \mathrm{R}_{2}\right] \quad(\mathrm{R}=\mathrm{Me}$ meso-3 + rac - 3 , $\mathrm{CH}_{2} \mathrm{Ph}$ meso-4 $\left.+\mathrm{rac}-4\right)$ which were isolated as white (3) and yellow (4) microcrystalline solids and identified by elemental analysis and NMR spectroscopy. A definitive structural assignment of the meso-3 isomer was easily made because its NMR spectra show two singlets $\left({ }^{1} \mathrm{H}\right)$ and two signals $\left({ }^{13} \mathrm{C}\right)$ due to two non-equivalent zirconium-methyl groups whereas the rac-3 isomer shows one signal $\left({ }^{1} \mathrm{H}\right.$ and $\left.{ }^{13} \mathrm{C}\right)$ for both equivalent zirconium-methyl groups. The isomers occur in a molar ratio 1/0.9. Similarly, the methylene protons of the two non-equivalent benzyl-zirconium groups of the meso-4 isomer appear in the ${ }^{1} \mathrm{H}$ NMR spectrum as two multiplets whereas only one multiplet is observed for the equivalent benzyl-zirconium substituents of $\mathrm{rac}-4$ (see Section 4). The isomers occur in a ca. $2 / 1$ molar ratio.

The analogous dichloro zirconocene $\left[\mathrm{Zr}\left(\eta^{5}-\mathrm{C}_{5} \mathrm{H}_{5}\right)\right.$ $\left.\left\{\eta^{5}-\left(1-\mathrm{Ph}-3-\mathrm{Me}-\mathrm{C}_{5} \mathrm{H}_{3}\right)\right\} \mathrm{Cl}_{2}\right] 5$ with mixed cyclopentadienyl rings can be prepared by reaction of the lithium salt 1 with 1 equivalent of $\left[\mathrm{Zr}\left(\eta^{5}-\mathrm{C}_{5} \mathrm{H}_{5}\right) \mathrm{Cl}_{3} \cdot \mathrm{DME}\right]$ in toluene at room temperature and isolated in $79 \%$ yield as a yellow solid. Alkylation of complex 5 with $\mathrm{LiMe}$ and $\mathrm{MgCl}\left(\mathrm{CH}_{2} \mathrm{Ph}\right)$ in diethyl ether gave the dialkyl complexes $\left[\mathrm{Zr}\left(\eta^{5}-\mathrm{C}_{5} \mathrm{H}_{5}\right)\left\{\eta^{5}-\left(1-\mathrm{Ph}-3-\mathrm{Me}-\mathrm{C}_{5} \mathrm{H}_{3}\right)\right\} \mathrm{R}_{2}\right] \quad(\mathrm{R}=\mathrm{Me} \quad \mathbf{6}$, $\mathrm{CH}_{2} \mathrm{Ph} 7$ ) which were isolated as a colourless oil and a yellow microcrystalline solid, respectively. Compounds 6-7 are soluble in all the usual organic solvents whereas 5 is partially soluble in alkanes and all three are very air sensitive compounds, although they can be stored for 


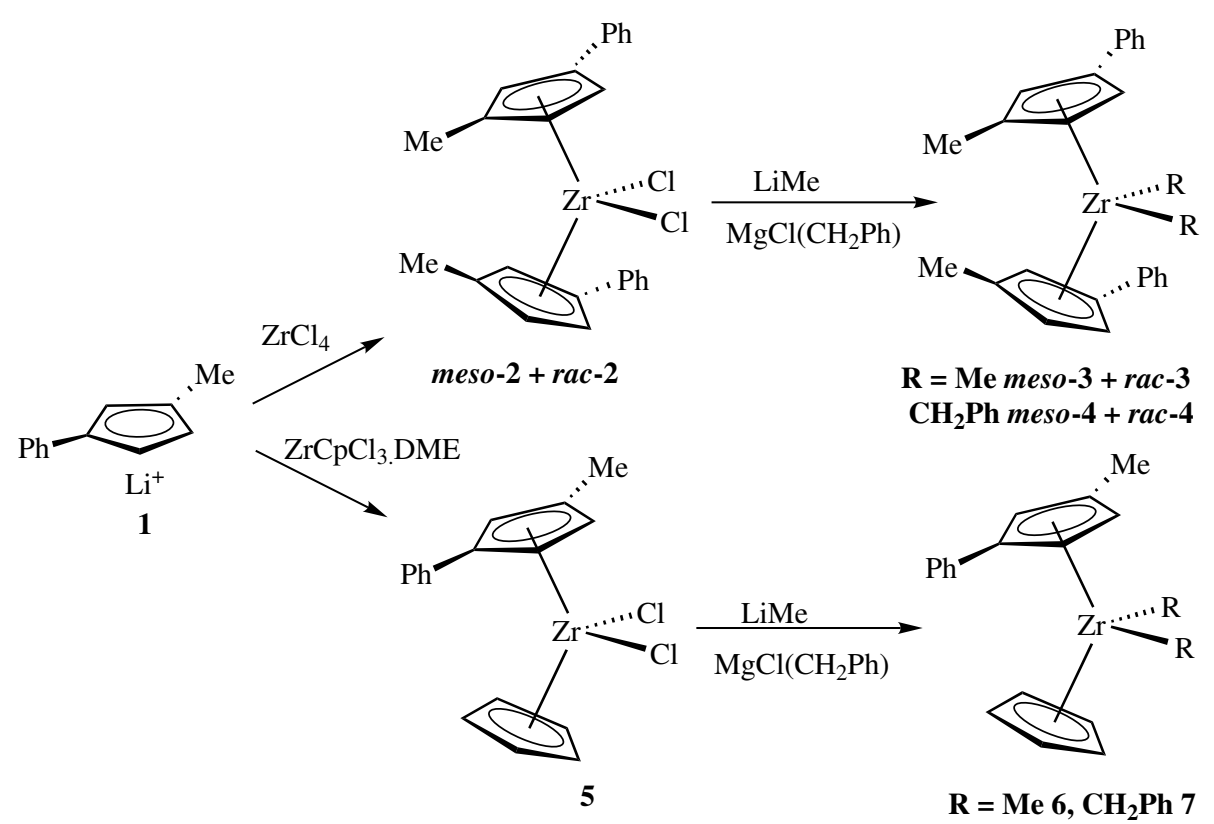

Scheme 2 .

long periods under an inert atmosphere. They were identified by elemental analysis and NMR spectroscopy. The enantiotopic face of the 1-3-disubstituted cyclopentadienyl ring makes the complexes 5-7 to be asymmetric molecules. Their ${ }^{1} \mathrm{H}$ and ${ }^{13} \mathrm{C}$ NMR spectra show three multiplets $\left({ }^{1} \mathrm{H}\right)$ and five signals $\left({ }^{13} \mathrm{C}\right)$ for the disubstituted-rings, three multiplets $\left({ }^{1} \mathrm{H}\right)$ and four signals $\left({ }^{13} \mathrm{C}\right)$ for the phenyl groups and two singlets $\left({ }^{1} \mathrm{H}\right)$ and two signals $\left({ }^{13} \mathrm{C}\right)$ due to the ring-methyl and the unsubstituted cyclopentadienyl groups. The non-equivalent methyl-zirconium groups appear as two singlets in the ${ }^{1} \mathrm{H}$ NMR spectrum of complex 6 whereas the expected four doublets were observed for the methylenic protons of the dibenzyl zirconium complex 7 (see Section 4).

\subsection{Disiloxane-bridged ansa-dicyclopentadienyl compl- exes}

Reaction of 2 equivalents of the dilithium salt 1 with the dichlorodisiloxane $\left[\left(\mathrm{SiMe}_{2} \mathrm{Cl}\right)_{2} \mathrm{O}\right]$ in THF afforded the dicyclopentadienylsiloxane $\left[\left(\mathrm{Me}-\mathrm{Ph}-\mathrm{C}_{5} \mathrm{H}_{3} \mathrm{SiMe}_{2}\right)_{2} \mathrm{O}\right]$ $\mathbf{8}$, which was isolated as a yellow-orange viscous liquid in $77 \%$ yield. Assuming that silicon is always bound to the $\mathrm{sp}^{3}$ ring-carbon atom, that the methyl and phenyl substituents are located at 2-4 positions with respect to the bridgehead carbon atom and that the silyl group is never located in $\alpha$ position with respect to both methyl and phenyl groups [17], three possible isomers of 8 could be formed. However the ${ }^{1} \mathrm{H}$ NMR spectrum of compound $\mathbf{8}$, probably containing a mixture of isomers showed very broad signals that prevented a reasonable structural assignment.

Deprotonation of $\mathbf{8}$ with 2 equivalents of $n \mathrm{BuLi}$ gave the dilithium salt $\mathrm{Li}_{2}\left[\left(\mathrm{Me}-\mathrm{Ph}-\mathrm{C}_{5} \mathrm{H}_{2} \mathrm{SiMe}_{2}\right)_{2} \mathrm{O}\right] 9$ which may also contain the corresponding mixture of isomers represented in Scheme 3. When this reaction was carried out in diethyl ether for $4 \mathrm{~h}$ at room temperature the insoluble dilithium salt was obtained by filtration in $32 \%$ yield as a white solid. The ${ }^{1} \mathrm{H}$ NMR spectrum of this compound in $\mathrm{C}_{6} \mathrm{D}_{6} / \mathrm{C}_{5} \mathrm{D}_{5} \mathrm{~N}$ showed one single set of signals corresponding to one unique isomer. It consists of one singlet for four equivalent Si-methyl groups, one singlet for two equivalent ring-methyl groups and the three signals expected for equivalent ring-phenyl groups, along with two doublets for the ring protons of two equivalent cyclopentadienyl rings (see Section 4). These spectral features are consistent with the structures proposed for 9a or $9 \mathbf{c}$ isomers which cannot be distinguished because each would have a similar set of signals. When the same reaction was carried out removing the solvent under vacuum without previous filtration, a yellowish solid was isolated in $60 \%$ yield. The ${ }^{1} \mathrm{H}$ NMR spectrum of this solid shows the same set of

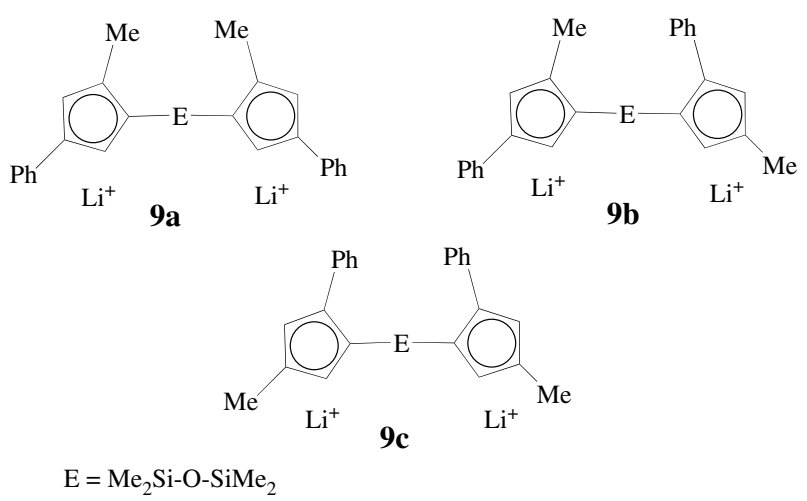

Scheme 3. 
signals observed for 9a or 9c and a new set consistent with that expected for the $\mathbf{9 b}$ isomer in a molar ratio $3: 1$, respectively. It shows two singlets each corresponding to two methyl protons of two non-equivalent $\mathrm{SiMe}_{2}$ groups and two singlets due to two non-equivalent ring methyl groups.

As shown in Scheme 4, reaction of $\mathrm{ZrCl}_{4} \cdot 2 \mathrm{THF}$ with 1 equivalent of the dilithium salt containing one single isomer (9a or $9 \mathbf{c})$ in toluene gave the dichlorozirconocene $\left[\mathrm{Zr}\left\{\eta^{5}-\left(\mathrm{Me}-\mathrm{Ph}-\mathrm{C}_{5} \mathrm{H}_{2} \mathrm{SiMe}_{2}\right)_{2} \mathrm{O}\right\} \mathrm{Cl}_{2}\right] \quad \mathbf{1 0}$ in $53 \%$ yield as a yellow crystalline solid which was characterized by elemental analysis and NMR spectroscopy. The ${ }^{1} \mathrm{H}$ NMR spectrum of $\mathbf{1 0}$ confirmed that it is a mixture of two diastereomers in a 6:1 molar ratio, each exhibiting a similar set of signals.

Recrystallization from toluene gave pure small crystals of the less soluble major component of this mixture. Although the crystals were too small for full analysis by X-ray diffraction methods and precise values for bond lengths and angles could not be determined, it was possible to obtain a sketch of its molecular structure which corresponds to the $\left[\mathrm{Zr}\left\{\eta^{5}-\left(2-\mathrm{Me}-4-\mathrm{Ph}-\mathrm{C}_{5} \mathrm{H}_{2} \mathrm{Si}-\right.\right.\right.$ $\left.\left.\mathrm{Me}_{2}\right)_{2} \mathrm{O}\right\} \mathrm{Cl}_{2}$ ] meso-10a diastereomer. The ${ }^{1} \mathrm{H}$ and ${ }^{13} \mathrm{C}$ NMR spectra are consistent with this structure. From the mother liquor it was possible to isolate samples containing the more soluble minor component although always contaminated by small variable amounts of meso-10a.
Crystals of this minor isomer of good quality suitable for X-ray diffraction were isolated and its molecular structure determined to confirm that it corresponds to the $\left[\mathrm{Zr}\left\{\eta^{5}-\left(2-\mathrm{Me}-4-\mathrm{Ph}-\mathrm{C}_{5} \mathrm{H}_{2} \mathrm{SiMe}_{2}\right)_{2} \mathrm{O}\right\} \mathrm{Cl}_{2}\right] \quad r a c-10 a$ diastereomer which is also consistent with the ${ }^{1} \mathrm{H}$ and ${ }^{13} \mathrm{C}$ NMR spectra. Therefore it is possible to conclude that the unique isomer detected in the starting dilithium salt is 9a, which reacts with $\mathrm{ZrCl}_{4} \cdot 2 \mathrm{THF}$ to give a mixture of the two possible meso-10a and rac-10a diastereomers.

When the same reaction with $\mathrm{ZrCl}_{4} \cdot 2 \mathrm{THF}$ was carried out using the dilithium salt containing a mixture of 9a and $\mathbf{9 b}$, the yellow solid isolated contained the same mixture of meso-10a and rac-10a coming from 9a together with a new isomer $\left[\mathrm{Zr}\left\{\eta^{5}-\left(2-\mathrm{Me}-4-\mathrm{Ph}-\mathrm{C}_{5} \mathrm{H}_{2}\right)[\mathrm{Si}-\right.\right.$ $\left.\left.\left.\left.\mathrm{Me}_{2}\right)_{2} \mathrm{O}\right]\left(\eta^{5}-\left(2-\mathrm{Ph}-4-\mathrm{Me}-\mathrm{C}_{5} \mathrm{H}_{2}\right)\right)\right\} \mathrm{Cl}_{2}\right]$ 10b, which could not be separated by repeated crystallization and was identified by NMR spectroscopy as one of the two possible diastereomers formed from $\mathbf{9 b}$, the molar ratio of the three isomers meso-10a: $r a c-10 a: 10 b$ was 1:0.6:0.7.

Similar reaction with $\mathrm{HfCl}_{4}$ gave a yellow solid containing a mixture in a 3:1 molar ratio of the meso-: $r a c$-diastereomers of the dichlorohafnocene $\left[\mathrm{Hf}\left\{\eta^{5}-(2-\right.\right.$ $\left.\left.\left.\mathrm{Me}-4-\mathrm{Ph}-\mathrm{C}_{5} \mathrm{H}_{2} \mathrm{SiMe}_{2}\right)_{2} \mathrm{O}\right\} \mathrm{Cl}_{2}\right]$ 11a containing insignificant amounts of the 11b isomer. This mixture could be enriched in the meso-11a diastereomer after repeated recrystallization from toluene to give a 15:1 molar ratio of the meso-rac diastereomers.

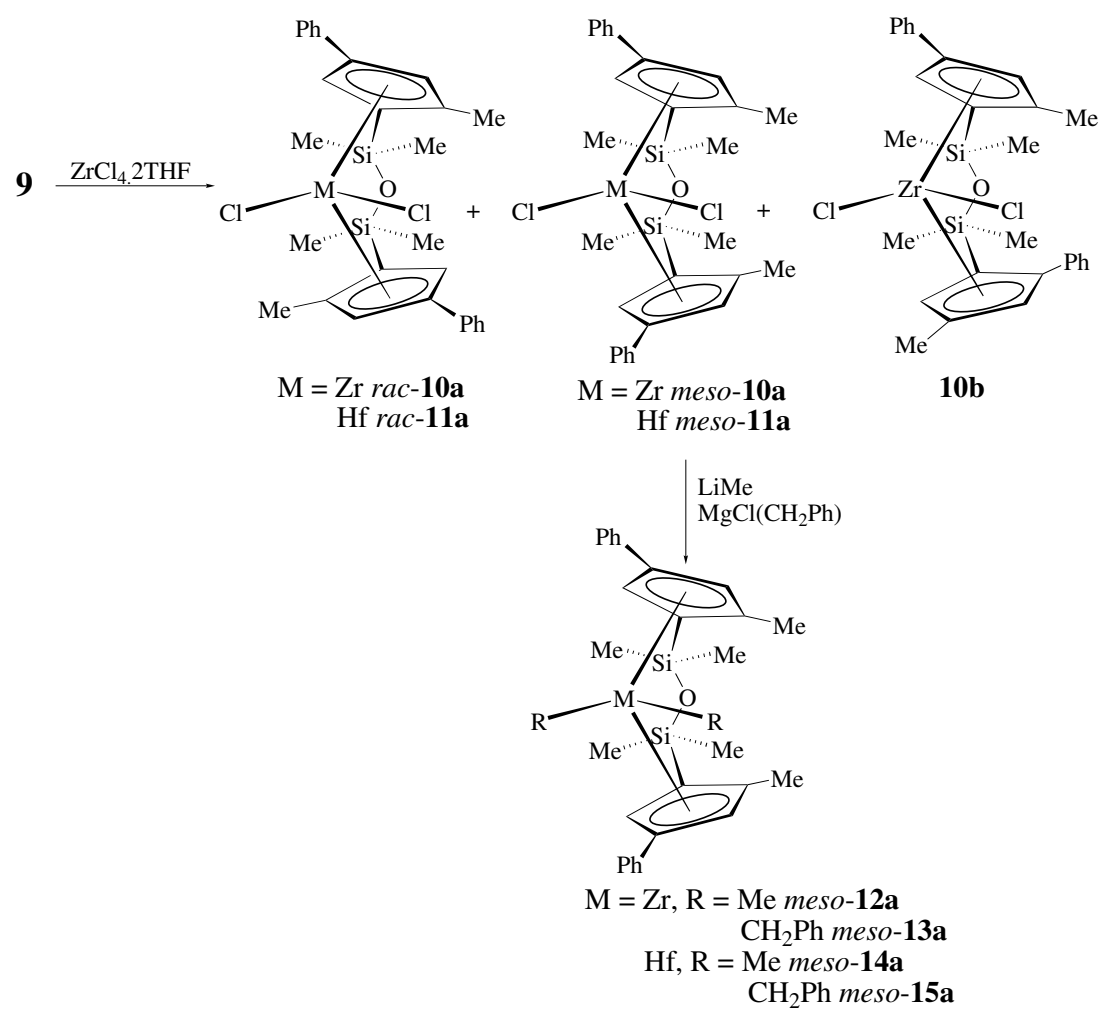

Scheme 4 
The ${ }^{1} \mathrm{H}$ and ${ }^{13} \mathrm{C}$ NMR spectra of $\mathbf{1 0 b}$ in $\mathrm{CDCl}_{3}$ showed four signals $\left({ }^{1} \mathrm{H},{ }^{13} \mathrm{C}\right)$ for methyl-silicon and two signals for methyl-ring groups consistent with its formulation as an asymmetric molecule. One of the ring methyl singlets is significantly shifted highfield $(\delta 1.51)$ probably due to the anisotropic effect on the methyl group located in $\alpha$-position, as it was also observed for the related dimethylsilylene-bridged compound identified as the meso-isomer by its X-ray molecular structure [17]. For this reason we tentatively assign the meso-configuration for $\mathbf{1 0 b}$.

According to the static structure determined by Xray diffraction studies the ${ }^{1} \mathrm{H}$ NMR spectra of the rac10a and rac-11a isomers should show four singlets for silicon-methyl and two singlets for ring-methyl groups whereas only two silicon-methyl and one ring-methyl singlets should be observed for the meso-10a and meso-11a isomers. However, it has been reported [6,9] that a dynamic exchange due to the twist of the siloxane group slipping between the two opposite sides of the ring takes place at room temperature with interconversion of these molecules into their mirror images. This fluxional behaviour also occurs for these metallocenes with two methyl-phenyl disubstituted rings exchanging the position of the silicon-methyl groups between the ring-methy- and phenyl substituents to give the averaged spectrum observed. This behaviour justifies the view that in solution at $25{ }^{\circ} \mathrm{C}$ the $r a c$-isomers give the same pattern of signals observed for the meso-isomers. The assignment of the two similar sets of signals observed in the NMR spectra of mixtures containing meso- and rac-10a was based on the spectra of isolated samples of each isomer and confirmed by their X-ray molecular structures. However, the structural assignment of meso- and rac-11a isomers suggested preparing the dialkyl derivatives for which the meso-isomer shows two easily identifiable non-equivalent alkyl groups, whereas the $r a c$-isomer should present equivalent alkyl groups.

Alkylation of the zirconium meso-10a isomer with LiMe and $\mathrm{MgCl}\left(\mathrm{CH}_{2} \mathrm{Ph}\right)$ in diethyl ether gave the meso-dialkyl complexes $\left[\mathrm{Zr}\left\{\eta^{5}-\left(2-\mathrm{Me}-4-\mathrm{Ph}-\mathrm{C}_{5} \mathrm{H}_{2} \mathrm{Si}-\right.\right.\right.$ $\left.\left.\mathrm{Me}_{2}\right)_{2} \mathrm{O}\right\} \mathrm{R}_{2}$ ] $\left(\mathrm{R}=\mathrm{Me}\right.$ meso-12a, $\mathrm{CH}_{2} \mathrm{Ph}$ meso-13a) as a colourless solid and a yellow oil, respectively. Similar alkylation of the hafnium dichloride $\mathbf{1 1}$ containing a mixture previously enriched to a molar ratio $15: 1$ of the meso- and $r a c$-isomers, respectively allowed isolation of pure meso-isomers $\left[\mathrm{Hf}\left\{\eta^{5}-\left(2-\mathrm{Me}-4-\mathrm{Ph}-\mathrm{C}_{5} \mathrm{H}_{2} \mathrm{Si}\right.\right.\right.$ $\left.\left.\left.\mathrm{Me}_{2}\right)_{2} \mathrm{O}\right\} \mathrm{R}_{2}\right]\left(\mathrm{R}=\mathrm{Me}\right.$ meso-14a, $\mathrm{CH}_{2} \mathrm{Ph}$ meso-15a), as a colourless solid and a yellow-orange oil, respectively, which were characterized by elemental analysis and NMR spectroscopy (see Section 4).

The X-ray molecular structure of $\mathrm{rac}-\mathbf{1 0 a}\left(1 S, 1^{\prime} S\right)$ enantiomer is shown in Fig. 1 with the atomic labelling scheme and selected bond lengths and angles are listed in Table 1.

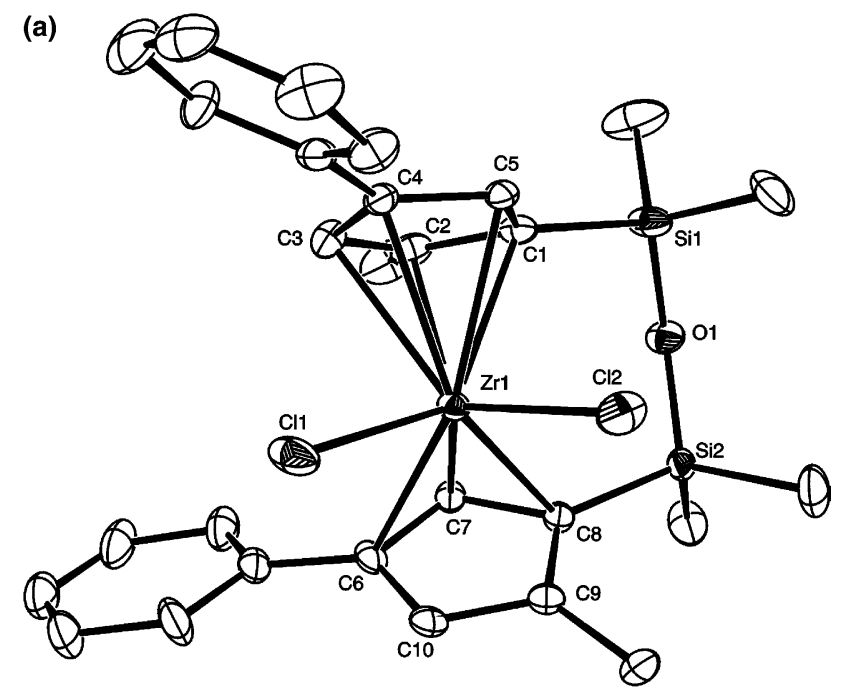

(b)

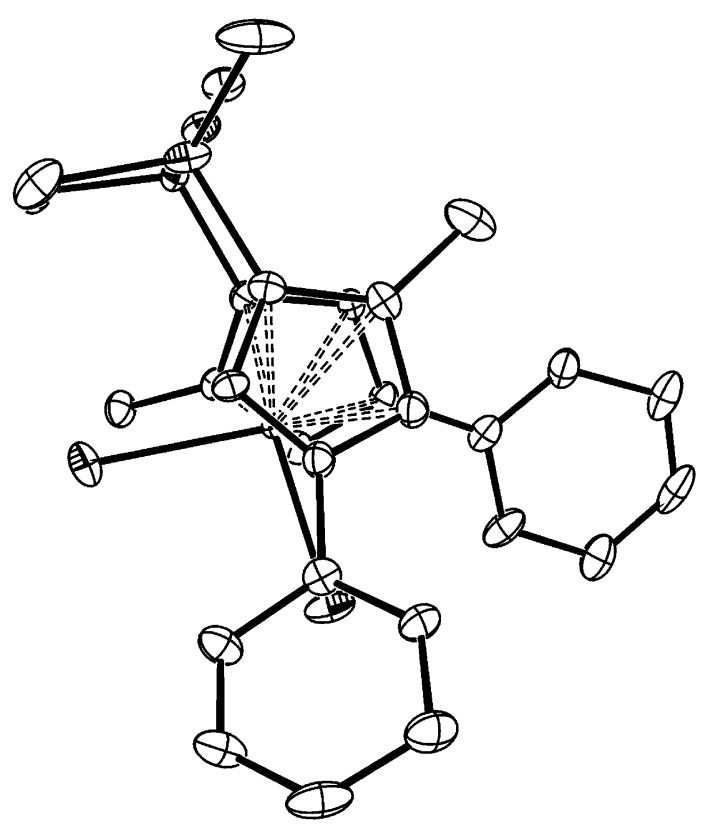

Fig. 1. ORTEP representation of the molecular structure of compound $r a c-10 a\left(1 S, 1^{\prime} S\right)$ enantiomer. Thermal ellipsoids are drawn at the $30 \%$ probability level. The $\mathrm{H}$ atoms were omitted for clarity. (a) View from the axis bisecting the $\mathrm{Cl}-\mathrm{Ti}-\mathrm{Cl}$ angle. (b) Top view perpendicular to the $\mathrm{ZrCl}_{2}$ plane.

The coordination geometry of the zirconium atom in rac-10a is similar to that observed in meso-10a both corresponding to the typical distorted tetrahedron formed by the ring centroids and the chlorine atoms as found for related titanocene [9] and zirconocene [3] derivatives with non-bridged or bridged cyclopentadienyl ligands. $\mathrm{The} \mathrm{Zr}-\mathrm{Cl}$ bond lengths for $\mathrm{rac}-\mathbf{1 0 a}$ are slightly different [Zr-Cl(1) 2.4274(11); $\mathrm{Zr}-\mathrm{Cl}(2)$ 2.4363(10) $\AA$ ], with the longer corresponding to the bond trans to the siloxy moiety. The $\mathrm{Cl}-\mathrm{Zr}-\mathrm{Cl}$ angle of $96.72(5)^{\circ}$ is within the range found for dichlorozirconocenes such as $\left[\mathrm{ZrCl}_{2}\left\{\mu-\left[\left(\eta^{5}-\mathrm{C}_{5} \mathrm{H}_{4}\right) \mathrm{SiMe}_{2} \mathrm{OSiMe}_{2}\left(\eta^{5}-\mathrm{C}_{5} \mathrm{H}_{4}\right)\right]\right\}\right][3]$ and 
Table 1

Selected interatomic distances (bonding and non-bonding, ̊) and bond angles $\left(^{\circ}\right)$ for $r a c-10 a\left(1 S, 1^{\prime} S\right)$ enantiomer

\begin{tabular}{|c|c|c|c|}
\hline \multicolumn{4}{|c|}{ Interatomic distances } \\
\hline $\operatorname{Zr}(1)-\mathrm{Cl}(1)$ & $2.4274(11)$ & $\mathrm{Zr}-\mathrm{Cp}(1)^{\mathrm{a}}$ & 2.2319 \\
\hline $\mathrm{Zr}(1)-\mathrm{Cl}(2)$ & $2.4363(10)$ & $\mathrm{Zr}-\mathrm{Cp}(2)^{\mathrm{a}}$ & 2.2378 \\
\hline $\operatorname{Zr}(1)-C(1)$ & $2.494(3)$ & $\mathrm{C}(1)-\mathrm{C}(2)$ & $1.436(5)$ \\
\hline $\operatorname{Zr}(1)-C(2)$ & $2.561(4)$ & $\mathrm{C}(2)-\mathrm{C}(3)$ & $1.397(5)$ \\
\hline $\operatorname{Zr}(1)-C(3)$ & $2.545(3)$ & $\mathrm{C}(3)-\mathrm{C}(4)$ & $1.420(5)$ \\
\hline $\operatorname{Zr}(1)-C(4)$ & $2.573(3)$ & $\mathrm{C}(4)-\mathrm{C}(5)$ & $1.402(4)$ \\
\hline $\operatorname{Zr}(1)-C(5)$ & $2.507(3)$ & $\mathrm{C}(1)-\mathrm{C}(5)$ & $1.425(5)$ \\
\hline $\operatorname{Zr}(1)-C(6)$ & $2.555(3)$ & $\mathrm{C}(2)-\mathrm{C}(21)$ & $1.514(5)$ \\
\hline $\mathrm{Zr}(1)-\mathrm{C}(7)$ & $2.482(3)$ & $\mathrm{C}(4)-\mathrm{C}(41)$ & $1.477(5)$ \\
\hline $\operatorname{Zr}(1)-C(8)$ & $2.500(3)$ & $\mathrm{C}(6)-\mathrm{C}(7)$ & $1.407(5)$ \\
\hline $\operatorname{Zr}(1)-C(9)$ & $2.596(3)$ & $\mathrm{C}(7)-\mathrm{C}(8)$ & $1.441(4)$ \\
\hline $\operatorname{Zr}(1)-\mathrm{C}(10)$ & $2.579(3)$ & $\mathrm{C}(8)-\mathrm{C}(9)$ & $1.425(5)$ \\
\hline $\mathrm{Si}(1)-\mathrm{C}(1)$ & $1.866(4)$ & $\mathrm{C}(9)-\mathrm{C}(10)$ & $1.407(5)$ \\
\hline $\mathrm{Si}(2)-\mathrm{C}(8)$ & $1.873(3)$ & $C(6)-C(10)$ & $1.420(5)$ \\
\hline $\operatorname{Si}(1)-C(11)$ & $1.839(5)$ & $\mathrm{C}(6)-\mathrm{C}(61)$ & $1.483(5)$ \\
\hline $\mathrm{Si}(1)-\mathrm{C}(12)$ & $1.849(5)$ & $\mathrm{C}(9)-\mathrm{C}(91)$ & $1.503(5)$ \\
\hline $\operatorname{Si}(2)-C(13)$ & $1.840(4)$ & $\mathrm{C}(2)^{\cdots \cdots} \mathrm{C}(7)$ & 3.126 \\
\hline $\operatorname{Si}(2)-C(14)$ & $1.846(4)$ & $\mathrm{C}(4)^{\cdots \cdots} \mathrm{C}(10)$ & 5.026 \\
\hline $\mathrm{O}(1)-\mathrm{Si}(1)$ & $1.640(3)$ & $\mathrm{C}(5)^{\cdots \cdot} \mathrm{C}(9)$ & 4.824 \\
\hline \multirow[t]{2}{*}{$\mathrm{O}(1)-\mathrm{Si}(2)$} & $1.633(3)$ & $\mathrm{C}(3)^{\cdots \cdots} \mathrm{C}(6)$ & 3.942 \\
\hline & & $\mathrm{C}(1)^{\cdots \cdots} \mathrm{C}(8)$ & 3.563 \\
\hline
\end{tabular}

Bond angles

$\begin{array}{llll}\mathrm{Cl}(1)-\mathrm{Zr}(1)-\mathrm{Cl}(2) & 96.72(5) & \mathrm{O}(1)-\mathrm{Si}(1)-\mathrm{C}(1) & 107.71(14) \\ \mathrm{Si}(2)-\mathrm{O}(1)-\mathrm{Si}(1) & 139.94(18) & \mathrm{O}(1)-\mathrm{Si}(2)-\mathrm{C}(8) & 108.22(14) \\ \mathrm{Cp}(1)-\mathrm{Zr}-\mathrm{Cp}(2)^{\mathrm{a}} & 132.74 & \mathrm{Cp}-\mathrm{Cp}^{\mathrm{b}} & 50.86\end{array}$

${ }^{\text {a }} \mathrm{Cp}(1)$ is the centroid of $\mathrm{C}(1), \mathrm{C}(2), \mathrm{C}(3), \mathrm{C}(4), \mathrm{C}(5)$ and $\mathrm{Cp}(2)$ is the centroid of $\mathrm{C}(6), \mathrm{C}(7), \mathrm{C}(8), \mathrm{C}(9), \mathrm{C}(10)$.

${ }^{\mathrm{b}}$ Dihedral angle between the least-squares cyclopentadienyl planes.

$\left[\mathrm{ZrCl}_{2}\left\{\mu-\left[\left(\eta^{5}-\mathrm{C}_{5} \mathrm{H}_{4}{ }^{-}{ }^{t} \mathrm{Bu}\right) \mathrm{SiMe}_{2} \mathrm{OSiMe}{ }_{2}\left(\eta^{5}-\mathrm{C}_{5} \mathrm{H}_{4}{ }^{-}{ }^{t} \mathrm{Bu}\right)\right]\right\}\right]$ [5]. The $\mathrm{Zr}-\mathrm{Cp}$ (centroid) distances [2.2319 and $2.2378 \AA$ ] are not significantly different from those observed in related compounds.

The $\mathrm{Si}-\mathrm{C}(\mathrm{Cp})$ bond lengths [average $1.870 \AA$ ] are slightly longer than the $\mathrm{Si}-\mathrm{C}(\mathrm{Me})$ distances [average $1.846 \AA$ ] , as previously observed in similar compounds $[3,5,9,16]$. The average $\mathrm{Si}-\mathrm{O}$ distances of $1.636 \AA$ are similar to those found in siloxanes. However, the $\mathrm{Si}-\mathrm{O}-$ $\mathrm{Si}$ angle $\left[139.94(18)^{\circ}\right]$ resembles that of $\left[\mathrm{ZrCl}_{2}\left\{\mu-\left[\left(\eta^{5}-\right.\right.\right.\right.$ $\left.\left.\left.\mathrm{C}_{5} \mathrm{H}_{4}{ }^{t} \mathrm{Bu}\right) \mathrm{SiMe}_{2} \mathrm{OSiMe}{ }_{2}\left(\eta^{5}-\mathrm{C}_{5} \mathrm{H}_{4}{ }^{t} \mathrm{Bu}\right)\right]\right\}$ ] [5] [138.1(3) ${ }^{\circ}$, which is significantly smaller than in $\left[\mathrm{ZrCl}_{2}\left\{\mu-\left[\left(\eta^{5}-\right.\right.\right.\right.$ $\left.\left.\left.\left.\mathrm{C}_{5} \mathrm{H}_{5}\right) \mathrm{SiMe}_{2} \mathrm{OSiMe}_{2}\left(\eta^{5}-\mathrm{C}_{5} \mathrm{H}_{5}\right)\right]\right\}\right]$ [3] [143.5(1) ${ }^{\circ}$ or in common open chain siloxanes $\left(142-145^{\circ}\right)$ [18]. This structural difference could be due to the steric congestion owing to the presence of the substituents in the ring.

The most remarkable features observed for $r a c-10 a$ are the eclipsed configuration of the two cyclopentadienyl rings (Fig. 1(b)) and the asymmetrical disposition of the bridge with respect to the bisector of the $\mathrm{Cl}-\mathrm{Zr}-\mathrm{Cl}$ angle as also found for related compounds with disiloxane bridges $[3,5,9,11]$. Both rings of $\mathrm{rac}-\mathbf{1 0 a}$ are tilted with an angle between the $\mathrm{Cp}$ planes of $50.86^{\circ}$ and a $\mathrm{Cp}$ (centroid) $\mathrm{Zr}-\mathrm{Cp}$ (centroid) angle of $132.74^{\circ}$, compa- rable to those reported for metallocenes containing nonbridged cyclopentadienyl ligands. This tilting brings the two $\alpha$-carbons $[C(2) \cdots \cdot C(7)]$ nearer $(3.126 \AA)$ whereas the distances between the distant carbons $[\mathrm{C}(4) \cdots \cdot \mathrm{C}(10)$ and $C(5) \cdots \cdot C(9)]$ are 5.026 and $4.824 \AA$, respectively, and those between the middle carbon atoms $[\mathrm{C}(3) \cdots \cdot \mathrm{C}(6)]$ and the bridgehead atoms $[\mathrm{C}(1) \cdots \cdot \mathrm{C}(8)]$ are 3.942 and $3.563 \AA$, respectively. This seems to be the most favourable disposition for the large bite of the disiloxane bridge in which the two $\eta^{5}$-coordinated cyclopentadienyl rings are almost identical, although the $\mathrm{C}(\mathrm{Cp})-\mathrm{Zr}$ bond distances are significantly spread out in a rather broad range between 2.482(3) and 2.596(3) $\AA$, as a consequence of the asymmetric disposition of the bridge. However significant differences are observed for the ring $\mathrm{C}-\mathrm{C}$ distances, the shortest being one of the internal distances [C(2)Me-C(3) 1.397(5) and $\mathrm{C}(6) \mathrm{Ph}-\mathrm{C}(7) 1.407(5) \AA]$ whereas the others, also internal with the bridgehead carbons are the longest $[\mathrm{C}(1)-\mathrm{C}(2) \mathrm{Me} 1.436(5)$ and $\mathrm{C}(7)-\mathrm{C}(8)$ 1.441(4) $\AA]$; the middle distances are exactly the same for both rings $[\mathrm{C}(3)-\mathrm{C}(4) \mathrm{Ph}$ and $\mathrm{C}(6) \mathrm{Ph}-\mathrm{C}(10)$ 1.420(5), $\mathrm{C}(1)-\mathrm{C}(5)$ and $\mathrm{C}(8)-\mathrm{C}(9) \mathrm{Me} 1.425(5) \AA]$, whereas the distal distances show intermediate values $[\mathrm{C}(4) \mathrm{Ph}-\mathrm{C}(5)$ 1.402(4) and $\mathrm{C}(9) \mathrm{Me}-\mathrm{C}(10)$ 1.407(5) $\mathrm{A}]$. These $\mathrm{C}-\mathrm{C}$ distances seem to be unaffected by the presence of the methyl and phenyl substituents.

\subsection{Olefin polymerization results}

The dichlorozirconocenes $\quad \mathrm{Zr}\left\{\eta^{5}-(1-\mathrm{Ph}-3-\mathrm{Me}-\right.$ $\left.\left.\left.\mathrm{C}_{5} \mathrm{H}_{3}\right)\right\}_{2} \mathrm{Cl}_{2}\right] 2$ (meso $\left.+\mathrm{rac}\right),\left[\mathrm{Zr}\left(\eta^{5}-\mathrm{C}_{5} \mathrm{H}_{5}\right)\left\{\eta^{5}-(1-\mathrm{Ph}-3-\right.\right.$ $\left.\left.\left.\mathrm{Me}-\mathrm{C}_{5} \mathrm{H}_{3}\right)\right\} \mathrm{Cl}_{2}\right] 5$ and $\left[\mathrm{Zr}\left\{\eta^{5}-\left(2-\mathrm{Me}-4-\mathrm{Ph}-\mathrm{C}_{5} \mathrm{H}_{2} \mathrm{Si}-\right.\right.\right.$ $\left.\left.\mathrm{Me}_{2}\right)_{2} \mathrm{O}\right\} \mathrm{Cl}_{2}$ ] meso-10a were used as catalyst precursors for the polymerization of ethene being activated with a large excess methylalumoxane (MAO: $\mathrm{Zr}=1500: 1)$ as a $10 \%$ toluene solution. All experiments were carried out in toluene under 1.0 bar of ethene in a glass reactor, using a $4.4 \times 10^{-3} \mathrm{M}$ toluene solution of the precursor zirconocene. Compounds $\mathbf{2}$ and $\mathbf{5}$ show activities between 1100 and $1300 \mathrm{~kg} \mathrm{~mol}^{-1} \mathrm{~h}^{-1}$ bar $^{-1}$ at $70^{\circ} \mathrm{C}$, slightly lower than that found for $\mathrm{Cp}_{2} \mathrm{ZrCl}_{2}\left(1500 \mathrm{~kg} \mathrm{~mol}^{-1} \mathrm{~h}^{-1} \mathrm{bar}^{-1}\right)$ used as reference under comparable conditions. The catalytic activity decreases slightly to values between 800 and $1000 \mathrm{~kg} \mathrm{~mol}^{-1} \mathrm{~h}^{-1}$ bar $^{-1}$ at $20^{\circ} \mathrm{C}$ and both catalysts display almost the same activities after 30 min accounting for their stability, although they decrease slowly for longer periods. The ansa-metallocene meso-10a shows a significantly lower activity (600 kg mol ${ }^{-1} \mathrm{~h}^{-1}$ bar $^{-1}$ ) which is almost independent of the temperature, decreasing slightly after $30 \mathrm{~min}$ under the same conditions. The molecular weight of the polyethylene resulting from catalyst $2\left(3.9 \times 10^{5} \mathrm{~g} \mathrm{~mol}^{-1}\right)$ is much higher than those coming from catalysts $5\left(1.6 \times 10^{4} \mathrm{~g} \mathrm{~mol}^{-1}\right)$ and meso-10a $\left(4.5 \times 10^{4} \mathrm{~g} \mathrm{~mol}^{-1}\right)$. However compound 2 which is a mixture of meso- and $\mathrm{rac}$-isomers gives a polyethylene of high 
polydispersity (7.6) accounting for the presence of more than one active centre, whereas the distribution of molecular weights is narrower for 5 (3.4) and meso-10a (3.6).

Compound meso-10a was also studied as catalyst precursor for polymerization of propene under 5.0 bar at $70{ }^{\circ} \mathrm{C}$. The catalytic activity was $200 \mathrm{~kg} \mathrm{~mol}^{-1} \mathrm{~h}^{-1}$ bar $^{-1}$ to give the expected atactic polymer.

\section{Conclusions}

The dichloro zirconocene complex $\left[\mathrm{Zr}\left\{\eta^{5}-(1-\mathrm{Ph}-3-\right.\right.$ Me- $\left.\left.\mathrm{C}_{5} \mathrm{H}_{3}\right)\right\}_{2} \mathrm{Cl}_{2}$ ] containing non-bridged cyclopentadienyl ligands is easily synthesized by transmetallation of the corresponding lithium salt to $\mathrm{ZrCl}_{4}$ resulting in formation of an approximately equimolar mixture of mesoand rac-diastereomers, which could not be separated by repeated recrystallization. However the corresponding dialkyl derivatives are easily distinguished by NMR spectroscopy, allowing a definitive assignment of their meso- and rac-configuration. Similar transmetallation to $\mathrm{CpZrCl}_{3}$ leads to the mixed-ring zirconocene complex $\left[\mathrm{Zr}\left(\eta^{5}-\mathrm{C}_{5} \mathrm{H}_{5}\right)\left\{\eta^{5}-\left(1-\mathrm{Ph}-3-\mathrm{Me}-\mathrm{C}_{5} \mathrm{H}_{3}\right)\right\} \mathrm{Cl}_{2}\right]$ for which the methyl and benzyl derivatives were also obtained.

Related dichloro ansa-zirconocene and hafnocene complexes $\left[\mathrm{M}\left\{\eta^{5}-\left(\mathrm{Me}-\mathrm{Ph}-\mathrm{C}_{5} \mathrm{H}_{2} \mathrm{SiMe}_{2}\right)_{2} \mathrm{O}\right\} \mathrm{Cl}_{2}\right]$ with tetramethyldisiloxane bridges are isolated by similar transmetallation reactions resulting in the formation of two types of isomers, namely those with $2,2^{\prime}-\mathrm{Me}_{2}-4,4^{\prime}-$ $\mathrm{Ph}_{2}-\left(\mathrm{C}_{5} \mathrm{H}_{2}\right)_{2}$ enantiofaces, leading to the corresponding meso- and rac-diastereomers and those with 2,4'- $\mathrm{Me}_{2}-$ $4,2^{\prime}-\mathrm{Ph}_{2}-\left(\mathrm{C}_{5} \mathrm{H}_{2}\right)_{2}$ enantiofaces for which formation of one unique diastereomer was observed. Most of these mixtures of diastereomers could be resolved by repeated recrystallization and single components were identified by NMR spectroscopy and X-ray diffraction methods. The structure and behaviour of these tetramethyldisiloxane-bridged ansa-metallocenes is similar to those reported for compounds of this type.

The three dichloro zirconocenes with non-bridged $\left[\mathrm{Zr}\left\{\eta^{5}-\left(1-\mathrm{Ph}-3-\mathrm{Me}-\mathrm{C}_{5} \mathrm{H}_{3}\right)\right\}_{2} \mathrm{Cl}_{2}\right] \quad$ (meso + rac $), \quad\left[\mathrm{Zr}\left(\eta^{5}-\right.\right.$ $\left.\left.\mathrm{C}_{5} \mathrm{H}_{5}\right)\left\{\eta^{5}-\left(1-\mathrm{Ph}-3-\mathrm{Me}-\mathrm{C}_{5} \mathrm{H}_{3}\right)\right\} \mathrm{Cl}_{2}\right]$ and bridged cyclopentadienyl rings meso- $\left[\mathrm{Zr}\left\{\eta^{5}-\left(2-\mathrm{Me}-4-\mathrm{Ph}-\mathrm{C}_{5} \mathrm{H}_{2} \mathrm{Si}\right.\right.\right.$ $\left.\left.\mathrm{Me}_{2}\right)_{2} \mathrm{O}\right\} \mathrm{Cl}_{2}$ ] activated with MAO show high catalytic activity for ethene polymerization comparable to $\mathrm{Cp}_{2} \mathrm{ZrCl}_{2}$ and the ansa meso-zirconocene is also an active catalyst for atactic polypropylene.

\section{Experimental}

\subsection{General methods}

All manipulations were performed under an inert atmosphere of argon using standard Schlenk techniques or a M. Braun dry box. Solvents used were previously dried and freshly distilled under argon. Deuterated solvents from Scharlau were degassed, dried and stored over molecular sieves. $\mathrm{MgBrPh}, \mathrm{MgCl}\left(\mathrm{CH}_{2} \mathrm{Ph}\right), \mathrm{MgSO}_{4}, n \mathrm{BuLi}$, $\mathrm{MeLi}, \mathrm{ZrCl}_{4}, \mathrm{HfCl}_{4},\left(\mathrm{Me}_{2} \mathrm{SiCl}\right)_{2} \mathrm{O}$ and $\mathrm{Me}_{2} \mathrm{SiCl}_{2}$ were obtained from commercial sources and used as received. [1-Ph-3-Me- $\left.\mathrm{C}_{5} \mathrm{H}_{3}\right] \mathrm{Li} 1$ [16], $\left[\mathrm{Zr}\left(\eta^{5}-\mathrm{C}_{5} \mathrm{H}_{5}\right) \mathrm{Cl}_{3} \cdot \mathrm{DME}\right]$ [19] and $\mathrm{ZrCl}_{4} \cdot 2 \mathrm{THF}$ [20] were isolated by reported methods.

${ }^{1} \mathrm{H}$ and ${ }^{13} \mathrm{C}$ NMR spectra were recorded on a Varian Unity VXR-300 or Varian Unity 500 Plus instruments. Chemical shifts, in ppm, are measured relative to residual ${ }^{1} \mathrm{H}$ and ${ }^{13} \mathrm{C}$ resonances for $\mathrm{C}_{6} \mathrm{H}_{6}-\mathrm{d}_{6}$ and $\mathrm{CHCl}_{3}-\mathrm{d}_{1}$ used as solvents and coupling constants are in $\mathrm{Hz}$. C, $\mathrm{H}$ analyses were carried out with a Perkin-Elmer 240$\mathrm{C}$ analyzer.

\subsection{Synthesis of $\left[\mathrm{Zr}\left\{\eta^{5}-\left(1-\mathrm{Ph}-3-\mathrm{Me}-\mathrm{C}_{5} \mathrm{H}_{3}\right)\right\}_{2} \mathrm{Cl}_{2}\right]$ (meso-2+rac-2)}

Hexane $(150 \mathrm{ml})$ was added to a mixture of the lithium salt $1(4.00 \mathrm{~g}, 24.60 \mathrm{mmol})$ and $\mathrm{ZrCl}_{4}(2.84 \mathrm{~g}, 12.30$ $\mathrm{mmol})$ at $-78^{\circ} \mathrm{C}$. The mixture was allowed to warm to room temperature and stirred for $12 \mathrm{~h}$. After filtration of the $\mathrm{LiCl}$, the solvent was removed under vacuum and the residue washed with hexane $(2 \times 20 \mathrm{ml})$ and dried under vacuum to give a yellow microcrystalline solid characterized as a mixture of meso-2 and rac-2 in a molar ratio 1:0.8 (4.32 g, $9.14 \mathrm{mmol}, 74 \%)$. ${ }^{1} \mathrm{H}$ NMR (300 MHZ, $\left.\mathrm{CDCl}_{3}, 25^{\circ} \mathrm{C}\right): 2.05^{\mathrm{a}} / 2.01^{\mathrm{b}}\left(\mathrm{s}, 6 \mathrm{H}, \mathrm{CH}_{3}\right), 5.77^{\mathrm{a}, \mathrm{b}}$ $\left(\mathrm{m}, 2 \mathrm{H}, \mathrm{C}_{5} H_{3}\right), 6.36^{\mathrm{a}} / 6.39^{\mathrm{b}}\left(\mathrm{m}, 2 \mathrm{H}, \mathrm{C}_{5} H_{3}\right), 6.45^{\mathrm{a}} / 6.42^{\mathrm{b}}$ $\left(\mathrm{m}, 2 \mathrm{H}, \mathrm{C}_{5} H_{3}\right), 7.01^{\mathrm{a}} / 7.06^{\mathrm{b}}\left(\mathrm{m}, 2 \mathrm{H}, H_{p} \mathrm{C}_{6} H_{5}\right), 7.12^{\mathrm{a}} /$ $7.17^{\mathrm{b}}\left(\mathrm{m}, 4 \mathrm{H}, H_{m} \mathrm{C}_{6} H_{5}\right), 7.31^{\mathrm{a}} / 7.34^{\mathrm{b}}\left(\mathrm{m}, 4 \mathrm{H}, H_{o} \mathrm{C}_{6} H_{5}\right)$. ${ }^{13} \mathrm{C}$ NMR $\left(75 \mathrm{MHz}, \mathrm{CDCl}_{3}, 25^{\circ} \mathrm{C}\right): 15.5^{\mathrm{a}} / 15.4^{\mathrm{b}}\left(\mathrm{CH}_{3}\right)$, $113.7^{\mathrm{a}} / 114.3^{\mathrm{b}}\left(C_{5} \mathrm{H}_{3}\right), 116.1^{\mathrm{a}} / 116.7^{\mathrm{b}}\left(C_{5} \mathrm{H}_{3}\right), 117.1^{\mathrm{a}} /$ $117.2^{\mathrm{b}}\left(C_{5} \mathrm{H}_{3}\right), 125.5^{\mathrm{a}} / 125.5^{\mathrm{b}}\left(C_{m} C_{6} \mathrm{H}_{5}\right), 125.7^{\mathrm{a}, \mathrm{b}}\left(C_{\text {ipso }^{-}}\right.$ $\left.\mathrm{Me}_{5} \mathrm{H}_{3}\right), 127.7^{\mathrm{a}} / 128.7^{\mathrm{b}}\left(C_{p} C_{6} \mathrm{H}_{5}\right), 129.0^{\mathrm{a}, \mathrm{b}}\left(C_{o} C_{6} \mathrm{H}_{5}\right)$, $129.7^{\mathrm{a}} / 130.0^{\mathrm{b}} \quad\left(C_{\mathrm{ipso}}-\mathrm{Ph} C_{5} \mathrm{H}_{3}\right), \quad 133.1^{\mathrm{a}} / 132.1^{\mathrm{b}} \quad\left(C_{\text {ipso }}{ }^{-}\right.$ $C_{6} \mathrm{H}_{5}$ ). Data for the major ${ }^{\mathrm{a}}$ and minor ${ }^{\mathrm{b}}$ isomers. Anal. Calc. for $\mathrm{C}_{24} \mathrm{H}_{22} \mathrm{Cl}_{2} \mathrm{Zr}$ : C, 61.00; H, 4.69. Found: C, $61.38 ; \mathrm{H}, 4.85 \%$.

\subsection{Synthesis of $\left[\mathrm{Zr}\left\{\eta^{5}-\left(1-\mathrm{Ph}-3-\mathrm{Me}-\mathrm{C}_{5} \mathrm{H}_{3}\right)\right\}_{2} \mathrm{Me}_{2}\right]$ (meso-3+rac-3)}

A $1.6 \mathrm{M} \mathrm{Et}_{2} \mathrm{O}$ solution of methyllithium $(0.90 \mathrm{ml}$, $1.60 \mathrm{mmol}$ ) was added at $-78{ }^{\circ} \mathrm{C}$ to a solution of meso-2 + rac-2 $(0.25 \mathrm{~g}, 0.53 \mathrm{mmol})$ in diethyl ether (30 $\mathrm{ml})$. The reaction mixture was stirred for $12 \mathrm{~h}$ while it was warmed slowly to room temperature. The solvent was removed under vacuum and the residue was extracted into hexane $(25 \mathrm{ml})$. After filtration, the solvent was removed at reduced pressure and the residue was dried under vacuum to give a white microcrystalline solid characterized as a mixture of meso-3 and rac-3 in a molar ratio 1:0.9 (0.19 g, $0.44 \mathrm{mmol}, 84 \%)$. meso-3: ${ }^{1} \mathrm{H}$ 
NMR (300 MHz, $\left.\mathrm{C}_{6} \mathrm{D}_{6}, 25^{\circ} \mathrm{C}\right):-0.21\left(\mathrm{~s}, 3 \mathrm{H}, \mathrm{Zr}-\mathrm{CH}_{3}\right)$, $-0.03\left(\mathrm{~s}, 3 \mathrm{H}, \mathrm{Zr}-\mathrm{CH}_{3}\right), 1.82\left(\mathrm{~s}, 6 \mathrm{H}, \mathrm{CH}_{3}\right), 5.57(\mathrm{~m}, 2 \mathrm{H}$, $\left.\mathrm{C}_{5} H_{3}\right), 5.86\left(\mathrm{~m}, 2 \mathrm{H}, \mathrm{C}_{5} H_{3}\right), 5.89\left(\mathrm{~m}, 2 \mathrm{H}, \mathrm{C}_{5} H_{3}\right), 6.99(\mathrm{~m}$, $\left.2 \mathrm{H}, H_{p} \mathrm{C}_{6} H_{5}\right), 7.09\left(\mathrm{~m}, 4 \mathrm{H}, H_{m} \mathrm{C}_{6} H_{5}\right), 7.16(\mathrm{~m}, 4 \mathrm{H}$, $\left.H_{o} \mathrm{C}_{6} H_{5}\right) .{ }^{13} \mathrm{C}$ NMR $\left(75 \mathrm{MHz}, \mathrm{C}_{6} \mathrm{D}_{6}, 25{ }^{\circ} \mathrm{C}\right): 16.0$ $\left(\mathrm{CH}_{3}\right), 33.7\left(\mathrm{Zr}-\mathrm{CH}_{3}\right), 34.9\left(\mathrm{Zr}-\mathrm{CH}_{3}\right), 108.3\left(C_{5} \mathrm{H}_{3}\right)$, $110.8\left(C_{5} \mathrm{H}_{3}\right), 113.9\left(C_{5} \mathrm{H}_{3}\right), 124.4\left(C_{\mathrm{ipso}}-\mathrm{Me}_{5} \mathrm{H}_{3}\right)$, $125.8\left(C_{m} C_{6} \mathrm{H}_{5}\right), 127.4\left(C_{p} C_{6} \mathrm{H}_{5}\right), 129.1\left(C_{\mathrm{ipso}}-\mathrm{PhC}_{5} \mathrm{H}_{3}\right)$, $129.6\left(C_{o} C_{6} \mathrm{H}_{5}\right), 135.9\left(C_{\mathrm{ipso}}-C_{6} \mathrm{H}_{5}\right) . r a c-3:{ }^{1} \mathrm{H}$ NMR $\left(300 \mathrm{MHz}, \mathrm{C}_{6} \mathrm{D}_{6}, 25^{\circ} \mathrm{C}\right):-0.11\left(\mathrm{~s}, 6 \mathrm{H}, \mathrm{Zr}-\mathrm{CH}_{3}\right), 1.87$ $\left(\mathrm{s}, 6 \mathrm{H}, \mathrm{CH}_{3}\right), 5.49\left(\mathrm{~m}, 2 \mathrm{H}, \mathrm{C}_{5} H_{3}\right), 5.80\left(\mathrm{~m}, 2 \mathrm{H}, \mathrm{C}_{5} H_{3}\right)$, $5.93\left(\mathrm{~m}, 2 \mathrm{H}, \mathrm{C}_{5} H_{3}\right), 6.99\left(\mathrm{~m}, 2 \mathrm{H}, H_{p} \mathrm{C}_{6} H_{5}\right), 7.09(\mathrm{~m}$, $\left.4 \mathrm{H}, H_{m} \mathrm{C}_{6} H_{5}\right), 7.16\left(\mathrm{~m}, 4 \mathrm{H}, H_{o} \mathrm{C}_{6} H_{5}\right) .{ }^{13} \mathrm{C}$ NMR $(75$ $\left.\mathrm{MHz}, \mathrm{C}_{6} \mathrm{D}_{6}, 25{ }^{\circ} \mathrm{C}\right): 16.1\left(\mathrm{CH}_{3}\right), 34.1\left(\mathrm{Zr}-\mathrm{CH}_{3}\right), 107.6$ $\left(C_{5} \mathrm{H}_{3}\right), 110.2 \quad\left(C_{5} \mathrm{H}_{3}\right), 113.8 \quad\left(C_{5} \mathrm{H}_{3}\right), 124.5 \quad\left(C_{\mathrm{ipso}^{-}}\right.$ $\left.\mathrm{Me}, C_{5} \mathrm{H}_{3}\right), 125.3\left(C_{m} C_{6} \mathrm{H}_{5}\right), 127.2 \quad\left(C_{p} C_{6} \mathrm{H}_{5}\right), 129.5$ $\left(C_{\mathrm{ipso}}-\mathrm{PhC}_{5} \mathrm{H}_{3}\right), 129.6\left(C_{o} C_{6} \mathrm{H}_{5}\right), 136.2\left(C_{\mathrm{ipso}}-C_{6} \mathrm{H}_{5}\right)$. Anal. Calc. for $\mathrm{C}_{26} \mathrm{H}_{28} \mathrm{Zr}$ : C, 72.33; H, 6.54. Found: C, $71.90 ; \mathrm{H}, 5.93 \%$.

\subsection{Synthesis of $\left[\mathrm{Zr}\left\{\eta^{5}-\left(1-\mathrm{Ph}-3-\mathrm{Me}-\mathrm{C}_{5} \mathrm{H}_{3}\right)\right\}_{2}\left(\mathrm{CH}_{2} \mathrm{Ph}\right)_{2}\right]-$ (meso-4+rac-4)}

A $2 \mathrm{M}$ THF solution of $\mathrm{MgClBz}(0.70 \mathrm{ml}, 1.40 \mathrm{mmol})$ was added at $-78{ }^{\circ} \mathrm{C}$ to a solution of $\mathbf{2}$ ( $\mathrm{rac}$ and meso) $(0.25 \mathrm{~g}, 0.53 \mathrm{mmol})$ in diethyl ether $(50 \mathrm{ml})$. The reaction mixture was stirred for $12 \mathrm{~h}$ while it was warmed slowly to room temperature. The solvent was removed under vacuum and the residue was extracted into hexane (50 $\mathrm{ml})$. The yellow solution was filtered and concentrated to $10 \mathrm{ml}$ under vacuum and cooled to $-30{ }^{\circ} \mathrm{C}$ to give a mixture of meso-4 and rac-4 in a molar ratio 1:0.5 as a yellow crystalline solid which was collected by filtration and dried under vacuum $(0.21 \mathrm{~g}, 0.40 \mathrm{mmol}$, 71\%). meso-4: ${ }^{1} \mathrm{H}$ NMR (300 MHz, $\left.\mathrm{C}_{6} \mathrm{D}_{6}, 25{ }^{\circ} \mathrm{C}\right): 1.67$ (m, $\left.2 \mathrm{H}, \mathrm{CH}_{2}-\mathrm{Ph}\right), 1.75\left(\mathrm{~m}, 2 \mathrm{H}, \mathrm{CH}_{2}-\mathrm{Ph}\right), 1.98(\mathrm{~s}, 6 \mathrm{H}$, $\left.\mathrm{CH}_{3}\right), 5.54\left(\mathrm{~m}, 2 \mathrm{H}, \mathrm{C}_{5} \mathrm{H}_{3}\right), 5.71\left(\mathrm{~m}, 2 \mathrm{H}, \mathrm{C}_{5} \mathrm{H}_{3}\right), 5.91$ $\left(\mathrm{m}, 2 \mathrm{H}, \mathrm{C}_{5} H_{3}\right), 6.98\left(\mathrm{~m}, 4 \mathrm{H}, \mathrm{C}_{6} H_{5}\right), 7.05(\mathrm{~m}, 8 \mathrm{H}$, $\left.\mathrm{C}_{6} H_{5}\right), 7.25\left(\mathrm{~m}, 8 \mathrm{H}, \mathrm{C}_{6} H_{5}\right) .{ }^{13} \mathrm{C}$ NMR $(75 \mathrm{MHz}$, $\left.\mathrm{C}_{6} \mathrm{D}_{6}, 25^{\circ} \mathrm{C}\right): 14.6\left(\mathrm{CH}_{3}\right), 65.8\left(\mathrm{Zr}-\mathrm{CH}_{2}-\mathrm{Ph}\right), 66.6(\mathrm{Zr}-$ $\left.\mathrm{CH}_{2} \mathrm{Ph}\right), 110.7\left(C_{5} \mathrm{H}_{3}\right), 113.4\left(C_{5} \mathrm{H}_{3}\right), 114.7\left(C_{5} \mathrm{H}_{3}\right)$, $121.5\left(C_{\mathrm{ipso}}-\mathrm{Me}_{5} \mathrm{H}_{3}\right), 125.5\left(C_{6} \mathrm{H}_{5}\right), 126.2\left(C_{6} \mathrm{H}_{5}\right)$, $126.7\left(C_{6} \mathrm{H}_{5}\right), \quad 127.6 \quad\left(C_{6} \mathrm{H}_{5}\right), \quad 128.3 \quad\left(C_{6} \mathrm{H}_{5}\right), 128.4$ $\left(C_{6} \mathrm{H}_{5}\right), \quad 128.6 \quad\left(C_{\mathrm{ipso}}-\mathrm{Ph} C_{5} \mathrm{H}_{3}\right), \quad 135.1 \quad\left(C_{\mathrm{ipso}}-C_{6} \mathrm{H}_{5}\right)$, $152.9\left(C_{\mathrm{ipso}}-\mathrm{CH}_{2}-P h\right)$. rac-4: ${ }^{1} \mathrm{H}$ NMR $(300 \mathrm{MHz}$, $\left.\mathrm{C}_{6} \mathrm{D}_{6}, 25^{\circ} \mathrm{C}\right): 1.75\left(\mathrm{~m}, 4 \mathrm{H}, \mathrm{CH}_{2}-\mathrm{Ph}\right), 1.98(\mathrm{~s}, 6 \mathrm{H}$, $\left.\mathrm{CH}_{3}\right), 5.54\left(\mathrm{~m}, 2 \mathrm{H}, \mathrm{C}_{5} \mathrm{H}_{3}\right), 5.76\left(\mathrm{~m}, 2 \mathrm{H}, \mathrm{C}_{5} \mathrm{H}_{3}\right), 5.91$ $\left(\mathrm{m}, 2 \mathrm{H}, \mathrm{C}_{5} H_{3}\right), 7.04\left(\mathrm{~m}, 4 \mathrm{H}, \mathrm{C}_{6} H_{5}\right), 7.07(\mathrm{~m}, 8 \mathrm{H}$, $\left.\mathrm{C}_{6} H_{5}\right), 7.22\left(\mathrm{~m}, 8 \mathrm{H}, \mathrm{C}_{6} H_{5}\right) .{ }^{13} \mathrm{C}$ NMR $(75 \mathrm{MHz}$, $\left.\mathrm{C}_{6} \mathrm{D}_{6}, 2{ }^{\circ} \mathrm{C}\right): 14.8\left(\mathrm{CH}_{3}\right), 64.1\left(\mathrm{Zr}-\mathrm{CH}_{2}-\mathrm{Ph}\right), 111.1$ $\left(C_{5} \mathrm{H}_{3}\right), \quad 112.9 \quad\left(C_{5} \mathrm{H}_{3}\right), \quad 115.1 \quad\left(C_{5} \mathrm{H}_{3}\right), \quad 124.3 \quad\left(C_{\text {ipso }^{-}}\right.$ $\left.\mathrm{Me}_{5} \mathrm{H}_{3}\right), 125.2\left(C_{6} \mathrm{H}_{5}\right), 126.4\left(C_{6} \mathrm{H}_{5}\right), 127.1\left(C_{6} \mathrm{H}_{5}\right)$, $128.5\left(C_{6} \mathrm{H}_{5}\right), 128.8\left(C_{6} \mathrm{H}_{5}\right), 128.9\left(C_{\text {ipso }}-\mathrm{Ph}_{5} \mathrm{H}_{3}\right)$, $135.0\left(C_{\mathrm{ipso}}-C_{6} \mathrm{H}_{5}\right), 153.1\left(C_{\mathrm{ipso}}-\mathrm{CH}_{2}-P h\right)$. Anal. Calc. for $\mathrm{C}_{38} \mathrm{H}_{36} \mathrm{Zr}$ : C, 78.16; $\mathrm{H}, 6.21$. Found: $\mathrm{C}, 78.35 ; \mathrm{H}$, $5.93 \%$.

\subsection{Synthesis of $\left[\mathrm{Zr}\left(\eta^{5}-\mathrm{C}_{5} \mathrm{H}_{5}\right)\left\{\eta^{5}-\left(1-\mathrm{Ph}-3-\mathrm{Me}-\mathrm{C}_{5} \mathrm{H}_{3}\right)\right\} \mathrm{Cl}_{2}\right](\mathbf{5})$}

Toluene $(100 \mathrm{ml})$ was added to a mixture of the lithium salt $1(3.00 \mathrm{~g}, 18.40 \mathrm{mmol})$ and $\left[\mathrm{Zr}\left(\eta^{5}-\mathrm{C}_{5} \mathrm{H}_{5}\right) \mathrm{Cl}_{3}\right.$. DME] $(6.52 \mathrm{~g}, 18.40 \mathrm{mmol})$ at $-78{ }^{\circ} \mathrm{C}$. The mixture was allowed to warm to room temperature and stirred for $12 \mathrm{~h}$. The yellow solution was filtered and after removal of the solvent under vacuum, the residue was washed with hexane $(60 \mathrm{ml})$ and dried under vacuum to give complex 5 as a yellow solid $(5.62 \mathrm{~g}, 14.70 \mathrm{mmol}$, $79 \%$ ). ${ }^{1} \mathrm{H}$ NMR $\left(300 \mathrm{MHz}, \mathrm{CDCl}_{3}, 25^{\circ} \mathrm{C}\right): 2.32$ (s, 3H, $\left.\mathrm{CH}_{3}\right), 6.18\left(\mathrm{~s}, 5 \mathrm{H}, \mathrm{C}_{5} H_{5}\right), 6.18\left(\mathrm{~m}, 1 \mathrm{H}, \mathrm{C}_{5} H_{3}\right), 6.65(\mathrm{~m}$, $\left.1 \mathrm{H}, \mathrm{C}_{5} H_{3}\right), 6.73\left(\mathrm{~m}, 1 \mathrm{H}, \mathrm{C}_{5} H_{3}\right), 7.30\left(\mathrm{~m}, 1 \mathrm{H}, H_{p} \mathrm{C}_{6} H_{5}\right)$, $7.42\left(\mathrm{~m}, 2 \mathrm{H}, H_{m} \mathrm{C}_{6} H_{5}\right), 7.53\left(\mathrm{~m}, 2 \mathrm{H}, H_{o} \mathrm{C}_{6} H_{5}\right) .{ }^{13} \mathrm{C}$ NMR $\left(75 \mathrm{MHz}, \mathrm{CDCl}_{3}, 25{ }^{\circ} \mathrm{C}\right): 15.6\left(\mathrm{CH}_{3}\right), 110.9$ $\left(C_{5} \mathrm{H}_{3}\right), 116.5\left(C_{5} \mathrm{H}_{5}\right), 117.2\left(C_{5} \mathrm{H}_{3}\right), 117.8\left(C_{5} \mathrm{H}_{3}\right)$, $125.8\left(C_{m} C_{6} \mathrm{H}_{5}\right), 125.9\left(C_{\mathrm{ipso}}-\mathrm{Me}_{5} C_{5} \mathrm{H}_{3}\right), 127.8\left(C_{p} C_{6} \mathrm{H}_{5}\right)$, $129.2\left(C_{o} C_{6} \mathrm{H}_{5}\right), 129.3\left(C_{\mathrm{ipso}}-\mathrm{Ph}_{5} \mathrm{H}_{3}\right), 133.8\left(C_{\mathrm{ipso}}{ }^{-}\right.$ $C_{6} \mathrm{H}_{5}$ ). Anal. Calc. for $\mathrm{C}_{17} \mathrm{H}_{16} \mathrm{Cl}_{2} \mathrm{Zr}$ : C, 53.39; $\mathrm{H}, 4.22$ Found: C, 52,91; H, 4.18\%.

4.6. Synthesis of $\left[\mathrm{Zr}\left(\eta^{5}-\mathrm{C}_{5} \mathrm{H}_{5}\right)\left\{\eta^{5}-\left(1-\mathrm{Ph}-3-\mathrm{Me}-\mathrm{C}_{5} \mathrm{H}_{3}\right)\right\}\right.$ $\left.\mathrm{Me}_{2}\right]$ (6)

A $1.6 \mathrm{M} \mathrm{Et}_{2} \mathrm{O}$ solution of methyllithium $(1.00 \mathrm{ml}$, $1.60 \mathrm{mmol}$ ) was added at $-78{ }^{\circ} \mathrm{C}$ to a solution of 5 $(0.41 \mathrm{~g}, 1.17 \mathrm{mmol})$ in diethyl ether $(20 \mathrm{ml})$. The reaction mixture was stirred for $12 \mathrm{~h}$ while it was warmed slowly to room temperature. The solvent was removed under vacuum and the residue was extracted into hexane ( 40 $\mathrm{ml})$. The colourless solution was filtered and after removal of the solvent under vacuum, complex 6 was collected as a colourless oil and dried under vacuum $(0.23$ g, $0.70 \mathrm{mmol}, 64 \%) .{ }^{1} \mathrm{H}$ NMR $\left(300 \mathrm{MHz}, \mathrm{C}_{6} \mathrm{D}_{6}, 25\right.$ $\left.{ }^{\circ} \mathrm{C}\right):-0.14\left(\mathrm{~s}, 3 \mathrm{H}, \mathrm{Zr}-\mathrm{CH}_{3}\right),-0.12\left(\mathrm{~s}, 3 \mathrm{H}, \mathrm{Zr}-\mathrm{CH}_{3}\right)$, $1.97\left(\mathrm{~s}, 3 \mathrm{H}, \mathrm{CH}_{3}\right), 5.62\left(\mathrm{~s}, 5 \mathrm{H}, \mathrm{C}_{5} H_{5}\right), 5.70(\mathrm{~m}, 1 \mathrm{H}$, $\left.\mathrm{C}_{5} H_{3}\right), 5.90\left(\mathrm{~m}, 1 \mathrm{H}, \mathrm{C}_{5} H_{3}\right), 5.97\left(\mathrm{~m}, 1 \mathrm{H}, \mathrm{C}_{5} H_{3}\right), 6.95$ $\left(\mathrm{t}, 1 \mathrm{H}, J=7.2, H_{p} \mathrm{C}_{6} H_{5}\right), 7.08\left(\mathrm{t}, 2 \mathrm{H}, J=7.3, H_{m} \mathrm{C}_{6} H_{5}\right)$, $7.16\left(\mathrm{~d}, 2 \mathrm{H}, J=7.2, H_{0} \mathrm{C}_{6} H_{5}\right) .{ }^{13} \mathrm{C}$ NMR $(75 \mathrm{MHz}$, $\left.\mathrm{C}_{6} \mathrm{D}_{6}, 25{ }^{\circ} \mathrm{C}\right): 15.2\left(\mathrm{CH}_{3}\right), 31.0\left(\mathrm{Zr}-\mathrm{CH}_{3}\right), 31.4(\mathrm{Zr}-$ $\left.\mathrm{CH}_{3}\right), 105.0\left(C_{5} \mathrm{H}_{3}\right), 109.2\left(C_{5} \mathrm{H}_{3}\right), 111.2\left(C_{5} \mathrm{H}_{5}\right), 112.9$ $\left(C_{5} \mathrm{H}_{3}\right), 124.4\left(C_{m} C_{6} \mathrm{H}_{5}\right), 125.0\left(C_{\mathrm{ipso}}-\mathrm{Me}_{5} C_{5} \mathrm{H}_{3}\right), 126.7$ $\left(C_{p} C_{6} \mathrm{H}_{5}\right), 128.8\left(C_{o} C_{6} \mathrm{H}_{5}\right), 128.9\left(C_{\mathrm{ipso}}-\mathrm{Ph}_{5} \mathrm{H}_{3}\right), 135.3$ $\left(C_{\mathrm{ipso}}-C_{6} \mathrm{H}_{5}\right)$. Anal. Calc. for $\mathrm{C}_{19} \mathrm{H}_{22} \mathrm{Zr}$ : C, 66.81; H, 6.49. Found: $\mathrm{C}, 66.94 ; \mathrm{H}, 6.72 \%$.

\subsection{Synthesis of $\left[\mathrm{Zr}\left(\eta^{5}-\mathrm{C}_{5} H_{5}\right)\left\{\eta^{5}-(1-\mathrm{Ph}-3-\mathrm{Me}-\right.\right.$ $\left.\left.\left.\mathrm{C}_{5} \mathrm{H}_{3}\right)\right\}\left(\mathrm{CH}_{2} \mathrm{Ph}\right)_{2}\right]$ ( 7)}

A $2 \mathrm{M}$ THF solution of $\mathrm{MgCl}\left(\mathrm{CH}_{2} \mathrm{Ph}\right)(1.90 \mathrm{ml}, 1.90$ mmol) was added at $-78{ }^{\circ} \mathrm{C}$ to a solution of $5(0.41 \mathrm{~g}$, $1.17 \mathrm{mmol})$ in diethyl ether $(20 \mathrm{ml})$. The reaction mixture was stirred for $12 \mathrm{~h}$ while it was warmed slowly to room temperature. The solvent was removed under vacuum and the residue was extracted into hexane (50 $\mathrm{ml})$. The yellow solution was filtered, concentrated to 
$10 \mathrm{ml}$ under vacuum and cooled to $-30{ }^{\circ} \mathrm{C}$ to give complex 7 as a yellow crystalline solid which was dried under vacuum $(0.71 \mathrm{~g}, 1.30 \mathrm{mmol}, 73 \%) .{ }^{1} \mathrm{H}$ NMR $(300 \mathrm{MHz}$, $\left.\mathrm{C}_{6} \mathrm{C}_{6}, 25^{\circ} \mathrm{C}\right): 1.81$ (d, $\left.1 \mathrm{H}, J=10.7, \mathrm{CH}_{2}-\mathrm{Ph}\right), 1.87$ (2d, $\left.2 \mathrm{H}, J=10.7, \mathrm{CH}_{2}-\mathrm{Ph}\right), 1.87\left(\mathrm{~s}, 3 \mathrm{H}, \mathrm{CH}_{3}\right), 1.95(\mathrm{~d}, 1 \mathrm{H}$, $\left.J=10.7, \mathrm{CH}_{2}-\mathrm{Ph}\right), 5.46\left(\mathrm{~s}, 5 \mathrm{H}, \mathrm{C}_{5} H_{5}\right), 5.71(\mathrm{~m}, 1 \mathrm{H}$, $\left.\mathrm{C}_{5} H_{3}\right), 5.79\left(\mathrm{~m}, 1 \mathrm{H}, \mathrm{C}_{5} H_{3}\right), 5.93\left(\mathrm{~m}, 1 \mathrm{H}, \mathrm{C}_{5} H_{3}\right), 6.91$ $\left(\mathrm{m}, 4 \mathrm{H}, \mathrm{C}_{6} H_{5}\right), 7.00\left(\mathrm{~m}, 4 \mathrm{H}, \mathrm{C}_{6} H_{5}\right), 7.08(\mathrm{~m}, 3 \mathrm{H}$, $\left.\mathrm{C}_{6} \mathrm{H}_{5}\right), 7.21\left(\mathrm{~m}, 4 \mathrm{H}, \mathrm{C}_{6} H_{5}\right) .{ }^{13} \mathrm{C}$ NMR $\left(75 \mathrm{MHz}, \mathrm{C}_{6} \mathrm{C}_{6}\right.$, $\left.25{ }^{\circ} \mathrm{C}\right): 14.9\left(\mathrm{CH}_{3}\right), 61.4\left(\mathrm{Zr}-\mathrm{CH}_{2}-\mathrm{Ph}\right), 62.2\left(\mathrm{Zr}-\mathrm{CH}_{2^{-}}\right.$ $\mathrm{Ph}), 106.8\left(C_{5} \mathrm{H}_{3}\right), 111.7\left(C_{5} \mathrm{H}_{3}\right), 113.6\left(C_{5} \mathrm{H}_{5}\right), 115.6$ $\left(C_{5} \mathrm{H}_{3}\right), 121.3\left(C_{6} \mathrm{H}_{5}\right), 123.5\left(C_{\mathrm{ipso}}-\mathrm{Me}_{5} \mathrm{H}_{3}\right), 124.5$ $\left(C_{6} \mathrm{H}_{5}\right), 124.8\left(C_{6} \mathrm{H}_{5}\right), 126.3\left(C_{6} \mathrm{H}_{5}\right), 126.1\left(C_{6} \mathrm{H}_{5}\right)$, $127.1 \quad\left(C_{6} \mathrm{H}_{5}\right), 128.5 \quad\left(C_{6} \mathrm{H}_{5}\right), 128.9\left(C_{\mathrm{ipso}}-\mathrm{Ph}_{5} \mathrm{H}_{3}\right)$, $134.7\left(C_{\mathrm{ipso}}-C_{6} \mathrm{H}_{5}\right), 152.6\left(C_{\mathrm{ipso}}-\mathrm{CH}_{2}-P h\right), 153.6\left(C_{\mathrm{ipso}^{-}}\right.$ $\mathrm{CH}_{2}-P h$ ). Anal. Calc. for $\mathrm{C}_{31} \mathrm{H}_{30} \mathrm{Zr}$ : C, 75.40; H, 6.12. Found: C, 74.93; H, 5.91\%.

\subsection{Synthesis of $\left[\left(\mathrm{Me}-\mathrm{Ph}-\mathrm{C}_{5} \mathrm{H}_{3} \mathrm{SiMe}_{2}\right)_{2} \mathrm{O}\right](\boldsymbol{8})$}

A solution of $\left(\mathrm{Me}_{2} \mathrm{SiCl}\right)_{2} \mathrm{O}(2.41 \mathrm{ml}, 12.30 \mathrm{mmol})$ in dry diethyl ether $(50 \mathrm{ml})$ was added dropwise to a solution of 2 equivalents of the lithium salt 1 ( $4.00 \mathrm{~g}, 24.60$ $\mathrm{mmol})$ in THF $(20.0 \mathrm{ml})$ at $0{ }^{\circ} \mathrm{C}$. After the addition was complete, the mixture was allowed to warm gradually to room temperature and then stirred for $12 \mathrm{~h}$. The solvents were removed under vacuum and the residue extracted into hexane and filtered to give a yellow solution. The hexane was then removed under vacuum to give a yellow oil characterized as compound 8 (4.32 g, $9.50 \mathrm{mmol}, 77 \%) .{ }^{1} \mathrm{H}$ NMR (300 MHz, $\mathrm{CDCl}_{3}, 25$ $\left.{ }^{\circ} \mathrm{C}\right):-0.25 /-0.15\left(\mathrm{SiCH}_{3}\right), 1.96 / 2.10\left(\mathrm{CH}_{3}\right), 3.18 / 3.39$ $\left(H \mathrm{C}_{\mathrm{sp} 3}\right) 5.93 / 6.67\left(H \mathrm{C}_{\mathrm{sp} 2}\right) 7.17 / 7.45(H \mathrm{Ph})$.

\subsection{Synthesis of $\mathrm{Li}_{2}\left[\left(\mathrm{Me}-\mathrm{Ph}-\mathrm{C}_{5} \mathrm{H}_{2} \mathrm{SiMe}_{2}\right)_{2} \mathrm{O}\right]$ (9)}

A 1.6 M hexane solution of $n$ BuLi (24.26 ml, 39.30 mmol) was added at $-78{ }^{\circ} \mathrm{C}$ to a stirred solution of 8 $(8.70 \mathrm{~g}, 19.60 \mathrm{mmol})$ in diethyl ether $(400 \mathrm{ml})$. The mixture was allowed to warm to room temperature and stirred for $4 \mathrm{~h}$. The resulting insoluble lithium salt was filtered, washed with hexane $(150 \mathrm{ml})$ and dried under vacuum to give a white solid characterized as the isomer 9a $(2.80 \mathrm{~g}, 6.26 \mathrm{mmol}, 32 \%)$. Following an alternative method the solvent was removed under vacuum from the suspension obtained after stirring for $4 \mathrm{~h}$ without previous separation of $9 \mathbf{a}$. The resulting solid residue was washed with hexane $(2 \times 100 \mathrm{ml})$ and dried under vacuum to give a yellowish solid characterized as a mixture of the $9 \mathbf{a}$ and $9 \mathbf{b}$ isomers in a molar ratio $3: 1(5.36 \mathrm{~g}$, $1.78 \mathrm{mmol}, 60 \%)$. ${ }^{1} \mathrm{H}$ NMR for $9 \mathrm{a}(300 \mathrm{MHz}$, pyridine$\mathrm{d}_{5} /$ benzene- $\left.\mathrm{d}_{6}, 25^{\circ} \mathrm{C}\right): 0.64\left(\mathrm{~s}, 12 \mathrm{H}, \mathrm{SiCH}_{3}\right), 2.56(\mathrm{~s}, 6 \mathrm{H}$, $\left.\mathrm{CH}_{3}\right), 6.11\left(\mathrm{~d}, 2 \mathrm{H}, J=1.8, \mathrm{C}_{5} \mathrm{H}_{2}\right), 6.71(\mathrm{~d}, 2 \mathrm{H}, J=2.3$, $\left.\mathrm{C}_{5} \mathrm{H}_{2}\right), 6.79\left(\mathrm{t}, 2 \mathrm{H}, J=8.0, H_{p} \mathrm{C}_{6} \mathrm{H}_{5}\right), 7.08(\mathrm{t}, 4 \mathrm{H}$, $\left.J=9.8, \quad H_{m} \mathrm{C}_{6} \mathrm{H}_{5}\right), 7.52\left(\mathrm{~d}, 4 \mathrm{H}, J=8.2, H_{o} \mathrm{C}_{6} \mathrm{H}_{5}\right) .{ }^{1} \mathrm{H}$ NMR for 9b $\left(300 \mathrm{MHz}\right.$, pyridine- $\mathrm{d}_{5} /$ benzene- $_{6}, 25$ $\left.{ }^{\circ} \mathrm{C}\right): 0.62\left(\mathrm{~s}, 6 \mathrm{H}, \mathrm{SiCH}_{3}\right), 0.68\left(\mathrm{~s}, 6 \mathrm{H}, \mathrm{SiCH}_{3}\right), 2.17$ (s, $\left.3 \mathrm{H}, \mathrm{C} H_{3}\right), 2.39\left(\mathrm{~s}, 3 \mathrm{H}, \mathrm{CH}_{3}\right), 6.15(\mathrm{~d}, 1 \mathrm{H}, J=2.0$, $\left.\mathrm{C}_{5} H_{2}\right), 6.29\left(\mathrm{~d}, 1 \mathrm{H}, J=2.3, \mathrm{C}_{5} H_{2}\right), 6.32(\mathrm{~d}, 1 \mathrm{H}, J=2.0$, $\left.\mathrm{C}_{5} H_{2}\right), 6.55\left(\mathrm{~d}, 1 \mathrm{H}, J=2.3, \mathrm{C}_{5} H_{2}\right), 6.94\left(\mathrm{~m}, 2 \mathrm{H}, \mathrm{C}_{6} H_{5}\right)$, $7.27\left(\mathrm{~m}, 4 \mathrm{H}, \mathrm{C}_{6} H_{5}\right), 7.56\left(\mathrm{~m}, 4 \mathrm{H}, \mathrm{C}_{6} H_{5}\right)$. Anal. Calc. for $\mathrm{C}_{28} \mathrm{H}_{32} \mathrm{Li}_{2} \mathrm{Si}_{2} \mathrm{O}: \mathrm{C}, 73.98 ; \mathrm{H}, 7.09$. Found: C, 73.23; $\mathrm{H}, 6.44 \%$.

4.10. Synthesis of $\left[\mathrm{Zr}\left\{\eta^{5}-\left(2-\mathrm{Me}-4-\mathrm{Ph}-\mathrm{C}_{5} \mathrm{H}_{2} \mathrm{SiMe}_{2}\right)_{2} \mathrm{O}\right\}-\right.$ $\left.\mathrm{Cl}_{2}\right]$ (meso-10a+rac-10a) and $\left[\mathrm{Zr}\left\{\eta^{5}-(2-\mathrm{Me}-4-\mathrm{Ph}-\right.\right.$ $\left.\mathrm{C}_{5} \mathrm{H}_{2}\right)\left[\left(\mathrm{SiMe}_{2}\right)_{2} \mathrm{O}\right]\left(\eta^{5}-\left(2-\mathrm{Ph}-4-\mathrm{Me}^{\left.-\mathrm{C}_{5} \mathrm{H}_{2}\right)}\right\} \mathrm{Cl}_{2}\right](\mathbf{1 0 b})$

\subsubsection{Method a}

Toluene $(20 \mathrm{ml})$ was added to a mixture of the dilithium salt 9a $(1.48 \mathrm{~g}, 3.25 \mathrm{mmol})$ and $\mathrm{ZrCl}_{4} \cdot 2 \mathrm{THF}(1.22 \mathrm{~g}$, $3.25 \mathrm{mmol}$ ) cooled at $-78{ }^{\circ} \mathrm{C}$. The light yellow suspension was allowed to warm to room temperature and stirred for $12 \mathrm{~h}$. After filtration of the $\mathrm{LiCl}$, the solution was concentrated to $15 \mathrm{ml}$ and cooled to $-30{ }^{\circ} \mathrm{C}$ to give a yellow crystalline solid $(1.03 \mathrm{~g}, 1.72 \mathrm{mmol}, 53 \%)$ identified as a mixture of two diastereomers (meso-10a, rac10a) in a molar ratio 6:1. Repeated recrystallization into toluene allowed pure samples of meso-10a to be isolated, whereas rac-10a was always contaminated by small amounts of meso-10a. meso-10a: ${ }^{1} \mathrm{H}$ NMR $(300 \mathrm{MHz}$, $\mathrm{CDCl}_{3}, 25^{\circ} \mathrm{C}$ ): 0.39 (s, $\left.6 \mathrm{H}, \mathrm{SiCH}_{3}\right), 0.51$ (s, $6 \mathrm{H}, \mathrm{SiCH}_{3}$ ), $2.40\left(\mathrm{~s}, 6 \mathrm{H}, \mathrm{CH}_{3}\right), 6.74\left(\mathrm{~d}, 2 \mathrm{H}, J=2.4, \mathrm{C}_{5} \mathrm{H}_{2}\right), 6.86(\mathrm{~d}$, $\left.2 \mathrm{H}, J=2.4, \mathrm{C}_{5} H_{2}\right), 7.11\left(\mathrm{~m}, 10 \mathrm{H}, \mathrm{C}_{6} H_{5}\right),{ }^{13} \mathrm{C} \mathrm{NMR}$ $\left(75 \mathrm{MHz}, \mathrm{CDCl}_{3}, 25{ }^{\circ} \mathrm{C}\right): 1.6\left(\mathrm{SiCH}_{3}\right), 2.7\left(\mathrm{SiCH}_{3}\right)$, $18.3\left(\mathrm{CH}_{3}\right), 113.2\left(C_{5} \mathrm{H}_{2}\right), 117.2\left(C_{\mathrm{ipso}}-\mathrm{Si}_{5} \mathrm{H}_{2}\right), 121.9$ $\left(C_{5} \mathrm{H}_{2}\right), \quad 125.7 \quad\left(C_{o} C_{6} \mathrm{H}_{5}\right), \quad 127.6 \quad\left(C_{p} C_{6} \mathrm{H}_{5}\right), \quad 128.4$ $\left(C_{m} C_{6} \mathrm{H}_{5}\right), 132.1\left(C_{\mathrm{ipso}}-\mathrm{Me} C_{5} \mathrm{H}_{2}\right), 133.2\left(C_{\mathrm{ipso}}-\mathrm{Ph} C_{5} \mathrm{H}_{2}\right)$, $142.0\left(C_{\mathrm{ipso}}-C_{6} \mathrm{H}_{5}\right) . \quad r a c-10 \mathrm{a}:{ }^{1} \mathrm{H}$ NMR $(300 \mathrm{MHz}$, $\mathrm{CDCl}_{3}, 25^{\circ} \mathrm{C}$ ): 0.29 (s, $\left.6 \mathrm{H}, \mathrm{SiCH}_{3}\right), 0.38$ (s, $6 \mathrm{H}, \mathrm{SiCH}_{3}$ ), $2.40\left(\mathrm{~s}, 6 \mathrm{H}, \mathrm{CH}_{3}\right), 6.46\left(\mathrm{~d}, 2 \mathrm{H}, J=2.2, \mathrm{C}_{5} H_{2}\right), 6.84(\mathrm{~d}$, $\left.2 \mathrm{H}, J=2.4, \mathrm{C}_{5} H_{2}\right), 7.24\left(\mathrm{~m}, 2 \mathrm{H}, H_{p} \mathrm{C}_{6} H_{5}\right), 7.33(\mathrm{~m}$, $\left.4 \mathrm{H}, H_{m} \mathrm{C}_{6} H_{5}\right), 7.59\left(\mathrm{~m}, 4 \mathrm{H}, H_{o} \mathrm{C}_{6} H_{5}\right) .{ }^{13} \mathrm{C}$ NMR $(75$ $\left.\mathrm{MHz}, \mathrm{CDCl}_{3}, 25{ }^{\circ} \mathrm{C}\right): 1.6\left(\mathrm{SiCH}_{3}\right), 2.2\left(\mathrm{SiCH}_{3}\right), 17.8$ $\left(C_{3}\right), \quad 113.2 \quad\left(C_{5} \mathrm{H}_{2}\right), \quad 116.1 \quad\left(C_{\mathrm{ipso}}-\mathrm{Si}_{5} \mathrm{C}_{5} \mathrm{H}_{2}\right), \quad 121.5$ $\left(C_{5} \mathrm{H}_{2}\right), \quad 126.8 \quad\left(C_{o} C_{6} \mathrm{H}_{5}\right), \quad 127.7 \quad\left(C_{p} C_{6} \mathrm{H}_{5}\right), \quad 128.2$ $\left(C_{m} C_{6} \mathrm{H}_{5}\right), 132.5\left(C_{\mathrm{ipso}}-\mathrm{Me}_{5} \mathrm{H}_{2}\right), 132.7\left(C_{\mathrm{ipso}}-\mathrm{Ph}_{C_{5}} \mathrm{H}_{2}\right)$, $136.5\left(C_{\mathrm{ipso}}-C_{6} \mathrm{H}_{5}\right)$. Anal. Calc. for $\mathrm{C}_{28} \mathrm{H}_{32} \mathrm{Si}_{2} \mathrm{OCl}_{2} \mathrm{Zr}$ : C, 55.79; H, 5.35. Found: C, 55.48; H, 5.40.f

\subsubsection{Method b}

The same procedure described in method a) was followed using the mixture of the lithium salts $9 \mathbf{a}$ and $9 \mathbf{b}$ to give a mixture containing meso-10a, rac-10a and 10b in a molar ratio 1:0.6:0.7. Pure samples of $\mathbf{1 0 b}$ could not be isolated by repeated recrystallization into toluene. ${ }^{1} \mathrm{H}$ NMR for $10 b\left(300 \mathrm{MHz}, \mathrm{CDCl}_{3}, 25^{\circ} \mathrm{C}\right):-0.05$ (s, $\left.3 \mathrm{H}, \mathrm{SiCH}_{3}\right), 0.33$ (s, $\left.3 \mathrm{H}, \mathrm{SiCH}_{3}\right), 0.40$ (s, $3 \mathrm{H}, \mathrm{SiCH}_{3}$ ), $0.60\left(\mathrm{~s}, 3 \mathrm{H}, \mathrm{SiCH}_{3}\right), 1.51\left(\mathrm{~s}, 3 \mathrm{H}, \mathrm{CH}_{3}\right), 2.27$ (s, $3 \mathrm{H}$, $\left.\mathrm{CH}_{3}\right), 6.27\left(\mathrm{~d}, 1 \mathrm{H}, J=2.3, \mathrm{C}_{5} H_{2}\right), 6.50(\mathrm{~d}, 1 \mathrm{H}, J=2.3$, $\left.\mathrm{C}_{5} H_{2}\right), 6.78\left(\mathrm{~d}, 1 \mathrm{H}, J=2.3, \mathrm{C}_{5} H_{2}\right), 7.14(\mathrm{~d}, 1 \mathrm{H}, J=2.3$, $\left.\mathrm{C}_{5} H_{2}\right), 7.24\left(\mathrm{~m}, 2 \mathrm{H}, H_{p} \mathrm{C}_{6} H_{5}\right), 7.33\left(\mathrm{~m}, 4 \mathrm{H}, H_{m} \mathrm{C}_{6} H_{5}\right)$, 
$7.61\left(\mathrm{~m}, 4 \mathrm{H}, H_{o} \mathrm{C}_{6} H_{5}\right) \cdot{ }^{13} \mathrm{C}$ NMR for $10 b(75 \mathrm{MHz}$, $\left.\mathrm{CDCl}_{3}, 25^{\circ} \mathrm{C}\right): 0.8\left(\mathrm{SiCH}_{3}\right), 1.4\left(\mathrm{SiCH}_{3}\right), 3.2\left(\mathrm{SiCH}_{3}\right)$, $3.3\left(\mathrm{SiCH}_{3}\right), 15.2\left(\mathrm{CH}_{3}\right), 18.1\left(\mathrm{CH}_{3}\right), 115.5\left(C_{5} \mathrm{H}_{2}\right)$, $117.7 \quad\left(C_{\mathrm{ipso}}-\mathrm{Si}_{5} \mathrm{H}_{2}\right), \quad 119.8 \quad\left(C_{\mathrm{ipso}}-\mathrm{Si}_{5} \mathrm{H}_{2}\right), \quad 122.0$ $\left(C_{5} \mathrm{H}_{2}\right), 122.9\left(C_{5} \mathrm{H}_{2}\right), 123.7\left(C_{5} \mathrm{H}_{2}\right), 126.0127 .4,127.8$, $128.0, \quad 128.6, \quad 143.1 \quad\left(C_{6} \mathrm{H}_{5}\right), \quad 130.1 \quad\left(C_{\mathrm{ipso}}-\mathrm{Me}_{5} \mathrm{H}_{2}\right)$, $135.0 \quad\left(C_{\mathrm{ipso}}-\mathrm{Me}_{5} \mathrm{H}_{2}\right), \quad 160.4 \quad\left(C_{\mathrm{ipso}}-\mathrm{Ph}_{5} \mathrm{H}_{2}\right), \quad 166.8$ $\left(C_{\mathrm{ipso}}-\mathrm{PhC}_{5} \mathrm{H}_{2}\right)$.

4.11. Synthesis of $\left[\mathrm{Hf}\left\{\eta^{5}-\left(2-\mathrm{Me}-4-\mathrm{Ph}-\mathrm{C}_{5} \mathrm{H}_{2} \mathrm{Si}\right.\right.\right.$ $\left.\left.\left.\mathrm{Me}_{2}\right)_{2} \mathrm{O}\right\} \mathrm{Cl}_{2}\right]$ (meso-11a+rac-11a)

The same procedure described to prepare $\mathbf{1 0}$ from a mixture of the lithium salts $9 \mathbf{a}$ and $\mathbf{9 b}$ was followed using $\mathrm{HfCl}_{4}(1.04 \mathrm{~g}, 3.25 \mathrm{mmol})$ to obtain the ansa-metallocene 11a as a yellow crystalline solid $(0.90 \mathrm{~g}, 1.30 \mathrm{mmol}$, $58 \%$ ) containing a mixture of two diastereomers (meso11a and rac-11a) in a molar ratio $3: 1$, which was increased to $15: 1$ after repeated recrystallization into toluene. meso-11a: ${ }^{1} \mathrm{H}$ NMR $\left(300 \mathrm{MHz}, \mathrm{CDCl}_{3}, 25^{\circ} \mathrm{C}\right)$ : 0.37 (s, 6H, $\left.\mathrm{SiCH}_{3}\right), 0.48$ (s, 6H, $\left.\mathrm{SiCH}_{3}\right), 2.38\left(\mathrm{~s}, 6 \mathrm{H}, \mathrm{CH}_{3}\right.$ ), $6.73\left(\mathrm{~d}, 2 \mathrm{H}, J=2.4, \mathrm{C}_{5} \mathrm{H}_{2}\right), 6.84\left(\mathrm{~d}, 2 \mathrm{H}, J=2.4, \mathrm{C}_{5} \mathrm{H}_{2}\right)$, $7.01\left(\mathrm{~m}, 10 \mathrm{H}, \mathrm{C}_{6} H_{5}\right) .{ }^{13} \mathrm{C}$ NMR $\left(75 \mathrm{MHz}, \mathrm{CDCl}_{3}, 25\right.$ $\left.{ }^{\circ} \mathrm{C}\right): \quad 1.5 \quad\left(\mathrm{SiCH}_{3}\right), \quad 2.8 \quad\left(\mathrm{SiCH}_{3}\right), 18.1 \quad\left(\mathrm{CH}_{3}\right), 113.3$ $\left(C_{5} \mathrm{H}_{2}\right), \quad 117.7 \quad\left(C_{\mathrm{ipso}}-\mathrm{Si}_{5} C_{5} \mathrm{H}_{2}\right), \quad 122.1 \quad\left(C_{5} \mathrm{H}_{2}\right), \quad 125.7$ $\left(C_{o} C_{6} \mathrm{H}_{5}\right), \quad 127.6 \quad\left(C_{p} C_{6} \mathrm{H}_{5}\right), 128.4 \quad\left(C_{m} C_{6} \mathrm{H}_{5}\right), 132.1$ $\left(C_{\text {ipso }}-\mathrm{MeC}_{5} \mathrm{H}_{2}\right), 142.1\left(C_{\mathrm{ipso}}-\mathrm{Ph} C_{5} \mathrm{H}_{2}\right), 170.0\left(C_{\mathrm{ipso}}-C_{6} \mathrm{H}_{5}\right)$. rac-11a: ${ }^{1} \mathrm{H}$ NMR $\left(300 \mathrm{MHz}, \mathrm{CDCl}_{3}, 25{ }^{\circ} \mathrm{C}\right.$ ): 0.35 (s, $\left.6 \mathrm{H}, \mathrm{SiCH}_{3}\right), 0.44\left(\mathrm{~s}, 6 \mathrm{H}, \mathrm{SiCH}_{3}\right), 2.37\left(\mathrm{~s}, 6 \mathrm{H}, \mathrm{CH}_{3}\right)$, $6.46\left(\mathrm{~d}, 2 \mathrm{H}, J=2.2, \mathrm{C}_{5} H_{2}\right), 6.85\left(\mathrm{~d}, 2 \mathrm{H}, J=2.3, \mathrm{C}_{5} H_{2}\right)$, $7.24\left(\mathrm{~m}, 2 \mathrm{H}, H_{p} \mathrm{C}_{6} H_{5}\right), 7.33\left(\mathrm{~m}, 4 \mathrm{H}, H_{m} \mathrm{C}_{6} H_{5}\right), 7.61$ (m, $\left.4 \mathrm{H}, \mathrm{H}_{o} \mathrm{C}_{6} H_{5}\right) \cdot{ }^{13} \mathrm{C}$ NMR $\left(75 \mathrm{MHz}, \mathrm{CDCl}_{3}, 25{ }^{\circ} \mathrm{C}\right)$ : $1.7\left(\mathrm{SiCH}_{3}\right), 2.1\left(\mathrm{SiCH}_{3}\right), 17.7\left(\mathrm{CH}_{3}\right), 113.3\left(C_{5} \mathrm{H}_{2}\right)$, $117.2\left(C_{\mathrm{ipso}}-\mathrm{Si}_{5} \mathrm{H}_{2}\right), 121.6\left(C_{5} \mathrm{H}_{2}\right), 126.8\left(C_{o} C_{6} \mathrm{H}_{5}\right)$, $127.8\left(C_{p} C_{6} \mathrm{H}_{5}\right), 128.8\left(C_{m} C_{6} \mathrm{H}_{5}\right), 133.3\left(C_{\mathrm{ipso}}-\mathrm{Me}_{5} \mathrm{H}_{2}\right)$, $147.3\left(C_{\mathrm{ipso}}-\mathrm{Ph} C_{5} \mathrm{H}_{2}\right), 157.2\left(C_{\mathrm{ipso}}-C_{6} \mathrm{H}_{5}\right)$. Anal. Calc. for $\mathrm{C}_{28} \mathrm{H}_{32} \mathrm{Si}_{2} \mathrm{OCl}_{2} \mathrm{Hf}$ : C, 48.73; H, 4.67. Found: C, 48.32; H, 4.67.

\subsection{Synthesis of $\left[\mathrm{Zr}\left\{\eta^{5}-\left(2-\mathrm{Me}-4-\mathrm{Ph}-\mathrm{C}_{5} \mathrm{H}_{2} \mathrm{Si}\right.\right.\right.$ - $\left.\left.\left.\mathrm{Me}_{2}\right)_{2} \mathrm{O}\right\} \mathrm{Me}_{2}\right]$ (meso-12)}

A $1.6 \mathrm{M} \mathrm{Et}_{2} \mathrm{O}$ solution of methyllithium $(2.10 \mathrm{ml}$, $3.36 \mathrm{mmol}$ ) was added at $-78{ }^{\circ} \mathrm{C}$ to a solution of meso-10 (1.00 g, $1.65 \mathrm{mmol})$ in $20 \mathrm{ml}$ of ethyl ether. The reaction mixture was stirred for $12 \mathrm{~h}$ while it was warmed slowly to room temperature. The solvent was removed under vacuum and the residue was extracted into hexane $(30 \mathrm{ml})$. After filtration of the $\mathrm{LiCl}$, the solution was concentrated to $10 \mathrm{ml}$ under vacuum and cooled to $-30{ }^{\circ} \mathrm{C}$ to give meso-12 as a white crystalline solid $(0.57 \mathrm{~g}, 1.02 \mathrm{mmol}, 62 \%) .{ }^{1} \mathrm{H}$ NMR $(300 \mathrm{MHz}$, $\left.\mathrm{C}_{6} \mathrm{D}_{6}, 25{ }^{\circ} \mathrm{C}\right):-0.46\left(\mathrm{~s}, 3 \mathrm{H}, \mathrm{Zr}-\mathrm{CH}_{3}\right),-0.13$ (s, 3H, $\left.\mathrm{Zr}-\mathrm{CH}_{3}\right), 0.29\left(\mathrm{~s}, 6 \mathrm{H}, \mathrm{SiCH}_{3}\right), 0.36\left(\mathrm{~s}, 6 \mathrm{H}, \mathrm{SiCH}_{3}\right)$, $2.21\left(\mathrm{~s}, 6 \mathrm{H}, \mathrm{CH}_{3}\right), 6.05\left(\mathrm{~d}, 2 \mathrm{H}, J=2.4, \mathrm{C}_{5} H_{2}\right), 6.61(\mathrm{~d}$, $\left.2 \mathrm{H}, J=2.4, \mathrm{C}_{5} H_{2}\right), 6.97\left(\mathrm{~m}, 4 \mathrm{H}, \mathrm{C}_{6} H_{5}\right), 7.08(\mathrm{~m}, 6 \mathrm{H}$,
$\left.\mathrm{C}_{6} \mathrm{H}_{5}\right) .{ }^{13} \mathrm{C}$ NMR $\left(75 \mathrm{MHz}, \mathrm{C}_{6} \mathrm{D}_{6}, 25{ }^{\circ} \mathrm{C}\right): 1.9\left(\mathrm{SiCH}_{3}\right)$, $2.7(\mathrm{SiCH}), 17.2\left(\mathrm{CH}_{3}\right), 39.3\left(\mathrm{Zr}-\mathrm{CH}_{3}\right), 41.2\left(\mathrm{Zr}-\mathrm{CH}_{3}\right)$, $107.9\left(C_{5} \mathrm{H}_{2}\right), 117.6\left(C_{\mathrm{ipso}}-\mathrm{Si}_{5} \mathrm{H}_{2}\right), 125.4\left(C_{5} \mathrm{H}_{2}\right)$, $126.8 \quad\left(C_{o} C_{6} \mathrm{H}_{5}\right), 128.6 \quad\left(C_{p} C_{6} \mathrm{H}_{5}\right), 129.6 \quad\left(C_{m} C_{6} \mathrm{H}_{5}\right)$, $132.6\left(C_{\text {ipso }}-\mathrm{Me}_{5} \mathrm{H}_{2}\right), \quad 134.5\left(C_{\mathrm{ipso}}-\mathrm{Ph}_{5} C_{5} \mathrm{H}_{2}\right), 147.9$ $\left(C_{\text {ipso }}-C_{6} \mathrm{H}_{5}\right)$. Anal. Calc. for $\mathrm{C}_{30} \mathrm{H}_{38} \mathrm{Si}_{2} \mathrm{OZr}$ : C, 64.11; H, 6.81. Found: C, 64.08; H, 6.78 .

4.13. Synthesis of $\left[\mathrm{Zr}\left\{\eta^{5}-\left(2-\mathrm{Me}-4-\mathrm{Ph}_{-} \mathrm{C}_{5} \mathrm{H}_{2} \mathrm{Si}\right.\right.\right.$ $\left.\left.\left.\mathrm{Me}_{2}\right)_{2} \mathrm{O}\right\}\left(\mathrm{CH}_{2} \mathrm{Ph}\right)_{2}\right]$ (meso-13)

A $2 \mathrm{M}$ THF solution of $\mathrm{MgClBz}(1.60 \mathrm{ml}, 3.20$ mmol) was added to a solution of meso-10 (1.00 g, $1.65 \mathrm{mmol})$ in ethyl ether $(20 \mathrm{ml})$. The reaction mixture was stirred for $12 \mathrm{~h}$, the solvent was removed under vacuum and the residue was extracted into hexane $(30 \mathrm{ml})$. After filtration, the solvent was removed at reduced pressure and the residue was dried under vacuum to give a yellow oil characterized as meso-13 (0.55 g, $0.77 \mathrm{mmol}, 47 \%) .{ }^{1} \mathrm{H}$ NMR $(300 \mathrm{MHz}$, $\left.\mathrm{C}_{6} \mathrm{D}_{6}, 25^{\circ} \mathrm{C}\right): 0.31\left(\mathrm{~s}, 6 \mathrm{H}, \mathrm{SiCH}_{3}\right), 0.34\left(\mathrm{~s}, 6 \mathrm{H}, \mathrm{SiCH}_{3}\right)$, $1.32\left(\mathrm{~m}, 2 \mathrm{H}, \mathrm{CH}_{2}-\mathrm{Ph}\right), 1.79\left(\mathrm{~m}, 2 \mathrm{H}, \mathrm{CH}_{2}-\mathrm{Ph}\right), 2.00(\mathrm{~s}$, $\left.6 \mathrm{H}, \mathrm{CH}_{3}\right), 6.31\left(\mathrm{~d}, 2 \mathrm{H}, J=2.4, \mathrm{C}_{5} H_{2}\right), 6.52(\mathrm{~d}, 2 \mathrm{H}$, $\left.J=2.4, \mathrm{C}_{5} \mathrm{H}_{2}\right), 6.84\left(\mathrm{~m}, 2 \mathrm{H}, \mathrm{C}_{6} \mathrm{H}_{5}\right.$ and $\left.\mathrm{CH}_{2}-P h\right), 7.00$ $\left(\mathrm{m}, 4 \mathrm{H}, \mathrm{C}_{6} \mathrm{H}_{5}\right.$ and $\left.\mathrm{CH}_{2}-\mathrm{Ph}\right), 7.07\left(\mathrm{~m}, 6 \mathrm{H}, \mathrm{C}_{6} \mathrm{H}_{5}\right.$ and $\left.\mathrm{CH}_{2}-\mathrm{Ph}\right), 7.25\left(\mathrm{~m}, 8 \mathrm{H}, \mathrm{C}_{6} \mathrm{H}_{5}\right.$ and $\left.\mathrm{CH}_{2}-\mathrm{Ph}\right) .{ }^{13} \mathrm{C} \mathrm{NMR}$ $\left(75 \mathrm{MHz}, \mathrm{C}_{6} \mathrm{D}_{6}, 25{ }^{\circ} \mathrm{C}\right): 1.6\left(\mathrm{SiCH}_{3}\right), 2.2\left(\mathrm{SiCH}_{3}\right)$, $16.8\left(\mathrm{CH}_{3}\right), 70.2\left(\mathrm{Zr}-\mathrm{CH}_{2} \mathrm{Ph}\right), 71.6\left(\mathrm{Zr}-\mathrm{CH}_{2} \mathrm{Ph}\right), 109.4$ $\left(\mathrm{CH}_{2}-\mathrm{Ph}\right), 114.2\left(C_{5} \mathrm{H}_{2}\right), 117.4\left(C_{\mathrm{ipso}}-\mathrm{SiC}_{5} \mathrm{H}_{2}\right), 121.9$ $\left(C_{5} \mathrm{H}_{2}\right), \quad 122.6 \quad\left(\mathrm{CH}_{2}-P h\right), \quad 126.4 \quad\left(C_{o} C_{6} \mathrm{H}_{5}\right), \quad 126.9$ $\left(\mathrm{CH}_{2}-\mathrm{Ph}\right), \quad 127.2\left(\mathrm{CH}_{2}-\mathrm{Ph}\right), \quad 127.5 \quad\left(C_{p} \mathrm{C}_{6} \mathrm{H}_{5}\right), 127.6$ $\left(\mathrm{CH}_{2}-\mathrm{Ph}\right), 127.8 \quad\left(\mathrm{CH}_{2}-\mathrm{Ph}\right), 128.1 \quad\left(\mathrm{CH}_{2}-\mathrm{Ph}\right), 128.5$ $\left(\mathrm{CH}_{2}-\mathrm{Ph}\right), \quad 128.7 \quad\left(C_{m} C_{6} \mathrm{H}_{5}\right), \quad 132.1 \quad\left(C_{\mathrm{ipso}}-\mathrm{MeC}_{5} \mathrm{H}_{2}\right)$, $134.1 \quad\left(C_{\mathrm{ipso}}-\mathrm{Ph} C_{5} \mathrm{H}_{2}\right), \quad 135.9 \quad\left(C_{\mathrm{ipso}}-\mathrm{CH}_{2}-P h\right), \quad 151.7$ $\left(C_{\mathrm{ipso}}-C_{6} \mathrm{H}_{5}\right), 152.8\left(C_{\mathrm{ipso}}-\mathrm{CH}_{2}-P h\right)$. Anal. Calc. for $\mathrm{C}_{42} \mathrm{H}_{46} \mathrm{Si}_{2} \mathrm{OZr}$ : C, 70.63; H, 6.49. Found: C, 70.56; $\mathrm{H}, 6.43$.

\subsection{Synthesis of $\left[\mathrm{Hf}\left\{\eta^{5}-\left(2-\mathrm{Me}-4-\mathrm{Ph}-\mathrm{C}_{5} \mathrm{H}_{2} \mathrm{Si}\right.\right.\right.$ - $\left.\left.\left.\mathrm{Me}_{2}\right)_{2} \mathrm{O}\right\} \mathrm{Me}_{2}\right]$ (meso-14)}

The same procedure described to prepare meso-12 was followed using a $1.6 \mathrm{M} \mathrm{Et}_{2} \mathrm{O}$ solution of methyllithium $(1.80 \mathrm{ml}, 2.89 \mathrm{mmol})$ and meso-11 containing small amounts of rac-11 (molar ratio 15:1) (1.00 g, $1.44 \mathrm{mmol})$ in $20 \mathrm{ml}$ of ethyl ether, to give pure meso-14 after recrystallization, as a white solid $(0.53 \mathrm{~g}, 0.81 \mathrm{mmol}, 57 \%) .{ }^{1} \mathrm{H}$ NMR $\left(300 \mathrm{MHz}, \mathrm{C}_{6} \mathrm{D}_{6}, 25^{\circ} \mathrm{C}\right):-0.45\left(\mathrm{~s}, 3 \mathrm{H}, \mathrm{Hf}-\mathrm{CH}_{3}\right)$, $-0.12\left(\mathrm{~s}, 3 \mathrm{H}, \mathrm{Hf}-\mathrm{CH}_{3}\right), 0.32\left(\mathrm{~s}, 6 \mathrm{H}, \mathrm{SiCH}_{3}\right), 0.37$ (s, $6 \mathrm{H}$, $\left.\mathrm{SiCH}_{3}\right), 2.11\left(\mathrm{~s}, 6 \mathrm{H}, \mathrm{CH}_{3}\right), 6.10\left(\mathrm{~d}, 2 \mathrm{H}, J=2.4, \mathrm{C}_{5} \mathrm{H}_{2}\right)$, $6.65\left(\mathrm{~d}, 2 \mathrm{H}, J=2.4, \mathrm{C}_{5} H_{2}\right), 7.00\left(\mathrm{~m}, 2 \mathrm{H}, H_{p} \mathrm{C}_{6} H_{5}\right)$, $7.02\left(\mathrm{~m}, 4 \mathrm{H}, H_{m} \mathrm{C}_{6} H_{5}\right), 7.52\left(\mathrm{~m}, 4 \mathrm{H}, H_{o} \mathrm{C}_{6} H_{5}\right) \cdot{ }^{13} \mathrm{C}$ NMR $\left(75 \mathrm{MHz}, \mathrm{C}_{6} \mathrm{D}_{6}, 25^{\circ} \mathrm{C}\right): 1.8\left(\mathrm{SiCH}_{3}\right), 2.6\left(\mathrm{SiCH}_{3}\right)$, $17.1\left(\mathrm{CH}_{3}\right), 39.2\left(\mathrm{Zr}-\mathrm{CH}_{3}\right), 41.1\left(\mathrm{Zr}-\mathrm{CH}_{3}\right), 107.7\left(\mathrm{C}_{5} \mathrm{H}_{2}\right)$, $17.4\left(C_{\mathrm{ipso}}-\mathrm{Si}_{5} C_{5} \mathrm{H}_{2}\right), 125.2\left(C_{5} \mathrm{H}_{2}\right), 126.6\left(C_{o} C_{6} \mathrm{H}_{5}\right), 128.1$ $\left(C_{p} C_{6} \mathrm{H}_{5}\right), 128.4\left(C_{m} C_{6} \mathrm{H}_{5}\right), 132.5\left(C_{\mathrm{ipso}}-\mathrm{Me}_{5} \mathrm{H}_{2}\right), 134.3$ 
$\left(C_{\mathrm{ipso}}-\mathrm{Ph}_{5} \mathrm{H}_{2}\right), 147.0 \quad\left(C_{\mathrm{ipso}}-C_{6} \mathrm{H}_{5}\right)$. Anal. Calc. for $\mathrm{C}_{30} \mathrm{H}_{38} \mathrm{Si}_{2} \mathrm{OHf}$ : C, 55.50; H, 5.90. Found: C, 55.48; H, $5.89 \%$.

\subsection{Synthesis of $\left[\mathrm{Hf}\left\{\eta^{5}-\left(2-\mathrm{Me}-4-\mathrm{Ph}-\mathrm{C}_{5} \mathrm{H}_{2} \mathrm{Si}\right.\right.\right.$ -} $\left.\left.\left.\mathrm{Me}_{2}\right)_{2} \mathrm{O}\right\}\left(\mathrm{CH}_{2} \mathrm{Ph}\right)_{2}\right]$ (meso-15)

The same procedure described to prepare meso- 14 was followed using a $2 \mathrm{M}$ THF solution of $\mathrm{MgClBz}$ $(1.45 \mathrm{ml}, 2.90 \mathrm{mmol})$ and meso-11 $(1.00 \mathrm{~g}, 1.44 \mathrm{mmol})$ in diethyl ether $(20 \mathrm{ml})$ to give meso-15 as a yellow-orange oil $(0.63 \mathrm{~g}, 0.79 \mathrm{mmol} ; 55 \%) .{ }^{1} \mathrm{H}$ NMR (300 $\left.\mathrm{MHz}, \mathrm{C}_{6} \mathrm{D}_{6}, 25{ }^{\circ} \mathrm{C}\right): 0.37$ (s, 6H, $\left.\mathrm{SiCH}_{3}\right), 0.39$ (s, 6H, $\left.\mathrm{SiCH}_{3}\right), 1.89\left(\mathrm{~m}, 2 \mathrm{H}, \mathrm{CH}_{2}-\mathrm{Ph}\right), 2.10\left(\mathrm{~m}, 2 \mathrm{H}, \mathrm{CH}_{2^{-}}\right.$ $\mathrm{Ph}), 2.30\left(\mathrm{~s}, 6 \mathrm{H}, \mathrm{CH}_{3}\right), 6.41\left(\mathrm{~m}, 4 \mathrm{H}, \mathrm{C}_{5} \mathrm{H}_{2}\right), 6.99(\mathrm{~m}$, $\left.8 \mathrm{H}, \mathrm{C}_{6} H_{5}\right), 7.05\left(\mathrm{~m}, 4 \mathrm{H}, \mathrm{C}_{6} H_{5}\right), 7.12\left(\mathrm{~m}, 8 \mathrm{H}, \mathrm{C}_{6} H_{5}\right)$. ${ }^{13} \mathrm{C}$ NMR $\left(75 \mathrm{MHz}, \mathrm{C}_{6} \mathrm{D}_{6}, 25{ }^{\circ} \mathrm{C}\right): 1.8\left(\mathrm{SiCH}_{3}\right), 2.9$ $\left(\mathrm{SiCH}_{3}\right), \quad 18.1 \quad\left(\mathrm{CH}_{3}\right), \quad 66.0 \quad\left(\mathrm{Zr}-\mathrm{CH}_{2} \mathrm{Ph}\right), 67.1 \quad(\mathrm{Zr}-$ $\left.\mathrm{CH}_{2} \mathrm{Ph}\right), 108.2\left(\mathrm{CH}_{2}-\mathrm{Ph}\right), 111.3\left(C_{5} \mathrm{H}_{2}\right), 118.9\left(C_{\mathrm{ipso}^{-}}\right.$

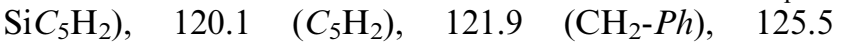
$\left(C_{o} C_{6} \mathrm{H}_{5}\right), \quad 126.0 \quad\left(\mathrm{CH}_{2}-P h\right), 127.5 \quad\left(\mathrm{CH}_{2}-P h\right), 127.8$ $\left(C_{p} C_{6} \mathrm{H}_{5}\right), 128.1 \quad\left(\mathrm{CH}_{2}-\mathrm{Ph}\right), 128.4 \quad\left(\mathrm{CH}_{2}-\mathrm{Ph}\right), 128.6$ $\left(\mathrm{CH}_{2}-\mathrm{Ph}\right), 129.6 \quad\left(\mathrm{CH}_{2}-\mathrm{Ph}\right), 130.1 \quad\left(C_{m} C_{6} \mathrm{H}_{5}\right), 133.1$ $\left(C_{\mathrm{ipso}}-\mathrm{MeC}_{5} \mathrm{H}_{2}\right), 138.6\left(C_{\mathrm{ipso}}-\mathrm{Ph} C_{5} \mathrm{H}_{2}\right), 139.8\left(C_{\text {ipso- }}{ }^{-}\right.$ $\left.\mathrm{CH}_{2}-P h\right), 141.8\left(C_{\mathrm{ipso}}-C_{6} \mathrm{H}_{5}\right), 150.8\left(C_{\mathrm{ipso}}-\mathrm{CH}_{2}-P h\right)$. Anal. Calc. for $\mathrm{C}_{42} \mathrm{H}_{46} \mathrm{Si}_{2} \mathrm{OHf}: \mathrm{C}, 62.94 ; \mathrm{H}, 5.78$. Found: C, 63.10; H, 5.60\%.

\subsection{X-ray crystallographic study of rac-10a}

Suitable single crystals for the X-ray diffraction study were grown by standard techniques from a saturated solution of rac-10a in toluene. Crystal colour, shape and size were yellow, prism, and $0.96 \times 0.41 \times 0.34 \mathrm{~mm}$, respectively. X-ray data were collected on a KappaCCD area detecting diffraction system using a Mo Ka radiation (See Table 2). The unit cell was determined from 172 reflections. Crystal structure was solved by direct methods (sIR 92 [21]) and refined using full-matrix least squares on $F^{2}$ (sHELXL 97 [22]). All non-hydrogen atoms were anisotropically refined. Hydrogen atoms were geometrically placed and left riding on their parent atoms. The racemic mixture of both enantiomers was observed.

\subsection{Polymerization procedures}

Polymerizations were carried out in a glass reactor equipped with a heating bath, magnetic stirrer and connection to argon-vacuum lines. The reactor was evacuated, flushed several times with argon and then charged at $25^{\circ} \mathrm{C}$ with $40 \mathrm{ml}$ of freshly distilled toluene and $4.0 \mathrm{ml}$ of a $10 \%$ toluene solution of MAO (MAO/ $\mathrm{Zr}=1500$ ). The solution was saturated with ethene at 1.0 bar and thermostatted at variable temperatures. Polymerization was started by injection of $1.0 \mathrm{ml}$ of a previously prepared $4.4 \times 10^{-3} \mathrm{M}$ toluene solution of
Table 2

Summary of crystal data and structure refinement parameters for rac10a

\begin{tabular}{ll}
\hline Empirical formula & $\mathrm{C}_{28} \mathrm{H}_{32} \mathrm{Cl}_{2} \mathrm{OSi}_{2} \mathrm{Zr}$ \\
\hline Formula weight & 602.84 \\
Temperature $(\mathrm{K})$ & $293(2)$ \\
Crystal system/space group & Monoclinic/P2 ${ }_{1} / n$ \\
Unit cell dimensions & \\
$\quad a(\AA)$ & $12.2763(19)$ \\
$b(\AA)$ & $18.377(3)$ \\
$\quad c(\AA)$ & $12.7789(8)$ \\
$\beta\left({ }^{\circ}\right)$ &, $100.072(7)$ \\
Volume $\left(\AA^{3}\right)$ & $2838.5(7)$ \\
$Z$ calculated density $\left(\mathrm{g} / \mathrm{cm}^{3}\right)$ & $4,1.411$ \\
Radiation Mo K $\alpha$ & 0.71073 \\
Absorption coefficient $\left(\mathrm{mm}^{-1}\right)$ & 0.679 \\
$F(000)$ & 1240 \\
$\Theta$ Range for data collection $\left({ }^{\circ}\right)$ & $3.07-27.50$ \\
Limiting indices & $-15 \leqslant h \leqslant 15,-23 \leqslant k \leqslant 23$, \\
& $-16 \leqslant l \leqslant 16$ \\
Reflections collected/unique $\left[R_{\text {int }}\right]$ & $53475 / 6445[0.1456]$ \\
Completeness to theta $=27.50$ & $98.9 \%$ \\
Absorption correction & Analytical \\
Max. and min. transmission & 0.792 and 0.724 \\
Data/restrains/parameters & $6445 / 0 / 307$ \\
Goodness-of-fit & 1.066 \\
Final $R$ indices $[I>2 \sigma(I)]$ & $R_{1}=0.0460, w R_{2}=0.0918$ \\
$R$ indices (all data) & $R_{1}=0.0891, w R_{2}=0.1113$ \\
Largest diff. peak and hole $\left(\mathrm{e} \AA^{3}\right)$ & 0.534 and -0.551 \\
\hline
\end{tabular}

the zirconocene catalyst. The reaction was stopped by addition of $5 \mathrm{ml}$ of acidified methanol $(1: 1 \mathrm{HCl} / \mathrm{metha}-$ nol). Polymers were recovered by filtration, washed with methanol and dried under vacuum at $80^{\circ} \mathrm{C}$ for $1 \mathrm{~d}$. The molecular weight of the resulting polyethylene was evaluated by GPC.

A similar procedure was followed for propene polymerization using a glass autoclave equipped with a heating bath, mechanical stirrer and connection to argonvacuum lines. The reactor was charged at $25^{\circ} \mathrm{C}$ with $600 \mathrm{ml}$ of freshly distilled heptane and $10.0 \mathrm{ml}$ of a $10 \%$ toluene solution of $\mathrm{MAO}(\mathrm{MAO} / \mathrm{Zr}=1500)$ and then saturated with propene at 5.0 bar and thermostatted at variable temperatures. Polymerization was started by injection of $0.01 \mathrm{mmol}$ of the zirconocene catalyst from a previously prepared toluene solution. The polymer was recovered and treated as described above.

\section{Supplementary material}

Crystallographic data for the structural analysis have been deposited with the Cambridge Crystallographic Data Centre, CCDC No. 237160 for rac-10a. Copies of this information may be obtained free of charge from The Director, CCDC, 12 Union Road, Cambridge CB2 1EZ, UK (fax: +44-1223-366-033; e-mail: deposit@ccdc.cam.ac.uk or http://www.ccdc.cam.ac.uk). 


\section{Acknowledgement}

We gratefully acknowledge Ministerio de Ciencia y Tecnología (project MAT2001-1309) for financial support. G.M. acknowledges Repsol-YPF and MECD for Fellowships. We thank T. Expósito (CSIC) for determination of molecular weights of polyethylene.

\section{References}

[1] (a) H.H. Brintzinger, D. Fischer, R. Mülhaupt, B. Rieger, R.M. Way mouth, Angew. Chem. Int. Ed. Engl. 34 (1995) 1143;

(b) M. Bochmann, J. Chem. Soc. Dalton Trans. (1996) 255;

(c) G.J.P. Britovsek, V.C. Gibson, D.F. Waas, Angew. Chem. Int. Ed. Engl. 38 (1999) 428;

(d) H.G. Alt, Chem. Rev. 100 (2000) 1205;

(e) G.W. Coates, Chem. Rev. 100 (2000) 1223.

[2] R.L. Schaaf, P.T. Kan, C.T. Lenk, J. Organomet. Chem. 26 (1961) 1790.

[3] S. Ciruelos, T. Cuenca, P. Gómez-Sal, A. Manzanero, P. Royo, Organometallics 14 (1995) 177.

[4] S. Ciruelos, A. Sebastián, T. Cuenca, P. Gómez-Sal, A. Manzanero, P. Royo, J. Organomet. Chem. 604 (2000) 103.

[5] J. Zemánek, M. Horácek, U. Thewalt, P. Stepnicka, J. Kubista, J. Cejka, L. Petrusová, K. Mach, Inorg. Chem. Commun. 4 (2001) 520.

[6] J. Gräper, G. Paolucci, R.D. Fischer, J. Organomet. Chem. 501 (1995) 211.
[7] J. Gräper, R.D. Fischer, G. Paolucci, J. Organomet. Chem. 471 (1994) 87.

[8] S.-S. Xu, T. Wu, H.-L. Cui, X.-L. Dai, B.-Q. Wang, X.-Z. Zou, Y. Li, Chem. J. Chin. Univ. 23 (2002) 1891.

[9] M.D. Curtis, J.J. D’Errico, D.N. Duffy, P.S. Epstein, L.G. Bell, Organometallics 2 (1983) 1808.

[10] W. Song, K. Shackett, J.C.W. Chien, M.D. Rausch, J. Organomet. Chem. 501 (1995) 375.

[11] H. Naderer, E. Siebel, R.D. Fischer, J. Organomet. Chem. 518 (1996) 181

[12] E. Ihara, M. Nodono, K. Katsura, Y. Adachi, H. Yasuda, M. Yamagashira, H. Hashimoto, N. Kanahisa, Y. Kai, Organometallics 17 (1996) 3945.

[13] J. Jung, S.K. Noh, D. Lee, S.K. Park, H. Kim, J. Organomet. Chem. 595 (2000) 147.

[14] S.K. Noh, G.G. Byun, C.S. Lee, D. Lee, K.B. Yoon, K.S. Kang, J. Organomet. Chem. 518 (1996) 1.

[15] D.H. Lee, S.K. Noh, K.B. Yoon, G.G. Byung, E.H. Lee, C.S Lee, Makromol. Chem. Rapid Commun. 16 (1995) 265.

[16] P. Burger, K. Hortmann, J. Diebold, H.-H. Brintzinger, J. Organomet. Chem. 417 (1991) 9.

[17] G. Martínez, P. Royo, E. Herdtweck, J. Organomet. Chem. 2004, submitted for publication.

[18] A.F. Wells, Structural Inorganic Chemistry, fifth ed., Clarendon, Oxford, 1984997.

[19] E.C. Lund, T. Livinghouse, Organometallics 9 (1990) 2426.

[20] L.E. Mancer, Inorg. Synth. 21 (1982) 134.

[21] A. Altomare, C. Cascarano, A. Giacovazzo, J. Guagliardi, Appl. Crystallogr. 26 (1993) 343.

[22] G.M. Sheldrick, SHELXL 97. University of Gottingen. A computer program for refinement of crystal structures, 1997. 